Prepared in cooperation with the U.S. Department of Energy, National Nuclear Security Administration Nevada Site Office, Office of Environmental Management, under Interagency Agreement, DE-NA0001654

\title{
Delineation of the Pahute Mesa-0asis Valley Groundwater Basin, Nevada
}



Scientific Investigations Report 2015-5175

Version 1.1, May 2016

U.S. Department of the Interior

U.S. Geological Survey 
Cover: Photograph of southern Oasis Valley near Beatty, Nevada, looking south toward the Amargosa Narrows. Photograph by Randy Laczniak, U.S. Geological Survey, 1997. 


\section{Delineation of the Pahute Mesa-0asis Valley Groundwater Basin, Nevada}

By Joseph M. Fenelon, Keith J. Halford, and Michael T. Moreo

Prepared in cooperation with the U.S. Department of Energy, National

Nuclear Security Administration Nevada Site Office, Office of Environmental

Management, under Interagency Agreement, DE-NA0001654

Scientific Investigations Report 2015-5175

Version 1.1, May 2016 


\title{
U.S. Department of the Interior SALLY JEWELL, Secretary
}

\section{U.S. Geological Survey Suzette M. Kimball, Director}

\author{
U.S. Geological Survey, Reston, Virginia \\ First release: 2016 \\ Revised: May 2016 (ver. 1.1)
}

For more information on the USGS - the Federal source for science about the Earth, its natural and living resources, natural hazards, and the environment—visit http://www.usgs.gov or call 1-888-ASK-USGS.

For an overview of USGS information products, including maps, imagery, and publications, visit http://www.usgs.gov/ pubprod/.

\footnotetext{
Any use of trade, firm, or product names is for descriptive purposes only and does not imply endorsement by the U.S. Government.

Although this information product, for the most part, is in the public domain, it also may contain copyrighted materials as noted in the text. Permission to reproduce copyrighted items must be secured from the copyright owner.

Suggested citation:

Fenelon, J.M., Halford, K.J., and Moreo, M.T., 2016, Delineation of the Pahute Mesa-Oasis Valley groundwater basin, Nevada (ver. 1.1, May 2016): U.S. Geological Survey Scientific Investigations Report 2015-5175, 40 p., http://dx.doi. org/10.3133/sir20155175.

ISSN 2328-0328 (online)
} 


\section{Contents}

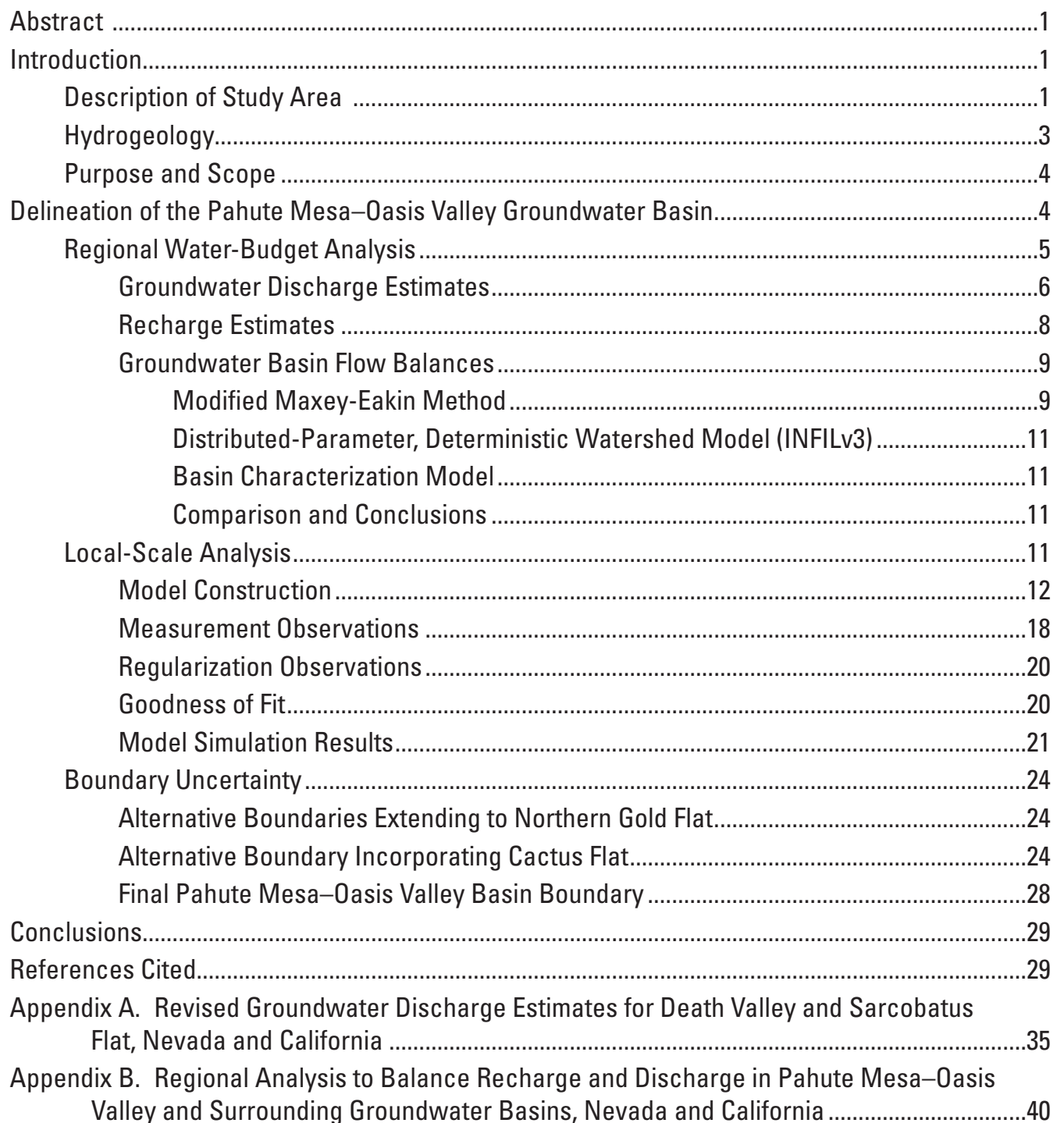

\section{Plate}

1. Map showing recharge, discharge, and groundwater flow in Pahute Mesa-Oasis Valley and surrounding groundwater basins, Nevada and California 


\section{Figures}

1. Map showing geographic features and groundwater basins in the region surrounding the Pahute Mesa-Oasis Valley groundwater basin, Nevada and California

2. Hydrogeologic section from Pahute Mesa to Oasis Valley, Nevada

3. Graph showing annual predevelopment groundwater discharge rates for Pahute Mesa-Oasis Valley and surrounding groundwater basins, Nevada and California .........8

4. Graph showing comparison of simulated recharge with measured discharge using the modified Maxey-Eakin method with two recharge ranges for Pahute Mesa-Oasis Valley and surrounding groundwater basins or subbasins, Nevada and California

5. Map showing extent of the steady-state PMOV flow model, hydrogeologic-unit distribution, measured water levels from selected wells, and groundwater-discharge area, Pahute Mesa-Oasis Valley groundwater basin, Nevada

6. Map showing PMOV flow model simulated transmissivity distribution, transmissivity observations from aquifer tests, simulated water levels, discharge area, and transmissivity pilot points, Pahute Mesa-Oasis Valley groundwater basin, Nevada..

7. Graphs showing relation between precipitation rate and conceptual recharge rate from infiltration and runoff to the PMOV flow model and cumulative recharge resulting from this relation, Pahute Mesa-Oasis Valley groundwater basin, Nevada ...15

8. Map showing PMOV flow model conceptual recharge rates used as initial condition for model, areas of low-permeability rock, water-level measurement locations, and discharge area, Pahute Mesa-Oasis Valley groundwater basin, Nevada

9. Map showing PMOV flow model simulated recharge rates from calibrated model, simulated water levels, chloride concentrations, discharge area, and recharge pilot points, Pahute Mesa-Oasis Valley groundwater basin, Nevada

10. Map showing PMOV flow model simulated water levels, water-level residuals, and discharge area, Pahute Mesa-Oasis Valley groundwater basin, Nevada

11. Graph showing comparison of simulated water levels for the calibrated PMOV flow model to estimated water levels in areas of groundwater evapotranspiration and measured water levels, Pahute Mesa-Oasis Valley groundwater basin, Nevada

12. Graph showing comparison of simulated and measured transmissivities for the PMOV flow model, Pahute Mesa-Oasis Valley groundwater basin, Nevada.

13. Map showing groundwater velocity field, simulated groundwater flow paths, simulated water levels, and underground nuclear tests in the PMOV flow model, Pahute Mesa-Oasis Valley groundwater basin, Nevada .....

14. Map showing boundaries investigated with regional and local-scale analyses to determine the contributing area for the Pahute Mesa-Oasis Valley groundwater basin, Nevada.

15. Map showing areas of low-permeability rock and groundwater flow directions in the Pahute Mesa-Oasis Valley groundwater basin and the Cactus Flat area, Nevada 


\section{Tables}

Table 1. Discharge areas and annual predevelopment discharge rates for Pahute

Mesa-Oasis Valley and surrounding groundwater basins, Nevada and California .........7

Table 2. Groundwater flow budgets and measured and calculated chloride concentrations in precipitation and groundwater for the final PMOV and Cactus Flat alternative groundwater basin boundaries, Pahute Mesa-Oasis Valley groundwater basin, Nevada

\section{Conversion Factors}

Inch/Pound to SI to International System of Units

\begin{tabular}{|c|c|c|}
\hline Multiply & By & To obtain \\
\hline \multicolumn{3}{|c|}{ Length } \\
\hline inch (in.) & 25.4 & millimeter $(\mathrm{mm})$ \\
\hline foot $(\mathrm{ft})$ & 0.3048 & meter $(\mathrm{m})$ \\
\hline mile (mi) & 1.609 & kilometer (km) \\
\hline \multicolumn{3}{|c|}{ Area } \\
\hline acre & 4,047 & square meter $\left(\mathrm{m}^{2}\right)$ \\
\hline square foot $\left(\mathrm{ft}^{2}\right)$ & 0.09290 & square meter $\left(\mathrm{m}^{2}\right)$ \\
\hline \multicolumn{3}{|c|}{ Volume } \\
\hline acre-foot (acre-ft) & 1,233 & cubic meter $\left(\mathrm{m}^{3}\right)$ \\
\hline cubic mile $\left(\mathrm{mi}^{3}\right)$ & 4.16818 & cubic kilometer $\left(\mathrm{km}^{3}\right)$ \\
\hline \multicolumn{3}{|c|}{ Flow rate } \\
\hline acre-foot per year (acre-ft/yr) & 1,233 & cubic meter per year $\left(\mathrm{m}^{3} / \mathrm{yr}\right)$ \\
\hline foot per year (ft/yr) & 0.3048 & meter per year (m/yr) \\
\hline inch per day (in/d) & 25.4 & millimeter per day $(\mathrm{mm} / \mathrm{d})$ \\
\hline inch per year (in/yr) & 25.4 & millimeter per year (mm/yr) \\
\hline \multicolumn{3}{|c|}{ Velocity } \\
\hline foot per day (ft/d) & 0.3048 & meter per day $(\mathrm{m} / \mathrm{d})$ \\
\hline \multicolumn{3}{|c|}{ Hydraulic gradient } \\
\hline foot per foot $(\mathrm{ft} / \mathrm{ft})$ & 1 & meter per meter $(\mathrm{m} / \mathrm{m})$ \\
\hline \multicolumn{3}{|c|}{ Transmissivity* } \\
\hline foot squared per day $\left(\mathrm{ft}^{2} / \mathrm{d}\right)$ & 0.09290 & meter squared per day $\left(\mathrm{m}^{2} / \mathrm{d}\right)$ \\
\hline
\end{tabular}

International System of Units to Inch/Pound

\begin{tabular}{lll}
\hline \multicolumn{1}{c}{ Multiply } & By & To obtain \\
\hline meter $(\mathrm{m})$ & Length & foot (ft) \\
kilometer $(\mathrm{km})$ & 3.281 & mile (mi) \\
\hline
\end{tabular}

Temperature in degrees Fahrenheit $\left({ }^{\circ} \mathrm{F}\right)$ may be converted to degrees Celsius $\left({ }^{\circ} \mathrm{C}\right)$ as ${ }^{\circ} \mathrm{C}=\left({ }^{\circ} \mathrm{F}-32\right) / 1.8$. 


\section{Datums}

Vertical coordinate information is referenced to the National Geodetic Vertical Datum of 1929 (NGVD 29).

Horizontal coordinate information is referenced to the North American Datum of 1983 (NAD 83).

Altitude, as used in this report, refers to distance above the vertical datum.

\section{Supplemental Information}

*Transmissivity: The standard unit for transmissivity is cubic foot per day per square foot times foot of aquifer thickness [(ft $\left.\left.\mathrm{ft}^{3} \mathrm{~d}\right) / \mathrm{ft}^{2}\right] \mathrm{ft}$. In this report, the mathematically reduced form, foot squared per day $\left(\mathrm{ft}^{2} / \mathrm{d}\right)$, is used for convenience.

Concentrations of chemical constituents in water are given in either milligrams per liter (mg/L) or micrograms per liter $(\mu \mathrm{g} / \mathrm{L})$.

\section{Abbreviations}

$\begin{array}{ll}\text { BCM } & \text { Basin Characterization Model } \\ \text { BREB } & \text { Bowen ratio energy budget } \\ \text { BSP } & \text { bare-soil playa } \\ \text { DEM } & \text { Digital-Elevation Model } \\ \text { ET } & \text { evapotranspiration } \\ \text { GWET } & \text { ET derived from groundwater discharge } \\ \text { MSAVI } & \text { modified soil adjusted vegetation index } \\ \text { NNSS } & \text { Nevada National Security Site } \\ \text { PMOV } & \text { Pahute Mesa-Oasis Valley } \\ \text { PEST } & \text { Parameter ESTimation code } \\ \text { PRISM } & \text { Parameter-elevation Regressions on Independent Slopes Model } \\ \text { RMS } & \text { root mean square } \\ \text { SEP } & \text { salt-encrusted playa } \\ \text { USGS } & \text { U.S. Geological Survey }\end{array}$




\title{
Delineation of the Pahute Mesa-0asis Valley Groundwater Basin, Nevada
}

\author{
By Joseph M. Fenelon, Keith J. Halford, and Michael T. Moreo
}

\section{Abstract}

This report delineates the Pahute Mesa-Oasis Valley (PMOV) groundwater basin, where recharge occurs, moves downgradient, and discharges to Oasis Valley, Nevada. About 5,900 acre-feet of water discharges annually from Oasis Valley, an area of springs and seeps near the town of Beatty in southern Nevada. Radionuclides in groundwater beneath Pahute Mesa, an area of historical underground nuclear testing at the Nevada National Security Site, are believed to be migrating toward Oasis Valley. Delineating the boundary of the PMOV groundwater basin is necessary to adequately assess the potential for transport of radionuclides from Pahute Mesa to Oasis Valley.

The PMOV contributing area is defined based on regional water-level contours, geologic controls, and knowledge of adjacent flow systems. The viability of this area as the contributing area to Oasis Valley and the absence of significant interbasin flow between the PMOV groundwater basin and adjacent basins are shown regionally and locally. Regional constraints on the location of the contributing area boundary and on the absence of interbasin groundwater flow are shown by balancing groundwater discharges in the PMOV groundwater basin and adjacent basins against available water from precipitation. Internal consistency for the delineated contributing area is shown by matching measured water levels, groundwater discharges, and transmissivities with simulated results from a single-layer, steady-state, groundwater-flow model. An alternative basin boundary extending farther north than the final boundary was rejected based on a poor chloride mass balance and a large imbalance in the northern area between preferred and simulated recharge.

\section{Introduction}

The investigation and long-term monitoring of radionuclides at the Nevada National Security Site (NNSS) are the focus of the U.S. Department of Energy Underground Test Area activity (U.S. Department of Energy, 2010). One of the objectives of the long-term activity is to assess the extent of contamination on and downgradient of the NNSS. Pahute Mesa, in the northwestern part of the NNSS, is of concern because groundwater is known to be contaminated, transport velocities are relatively fast (about $200 \mathrm{ft} / \mathrm{yr}$ ), and the travel distance between contaminated water and publicly accessible lands is relatively small (approximately $12 \mathrm{mi}$ ). Investigations of radionuclide movement away from Pahute Mesa have been occurring since the 1990s (U.S. Department of Energy, 1999; 2009).

Eighty-five nuclear tests were detonated on Pahute Mesa in deep vertical shafts, and more than 70 of the tests were near or below the water table (Laczniak and others, 1996; Pawloski and others, 2002). Tests below the water table typically were larger in explosive yield and detonated in deeper vertical shafts to prevent releases of radionuclide-laden gasses into the atmosphere. Some of these tests released radionuclides into the groundwater system (Laczniak and others, 1996; Pawloski and others, 2001; Wolfsberg and others, 2002; National Security Technologies, LLC, 2010a; 2010b).

Determining the boundary of the Pahute Mesa-Oasis Valley (PMOV) groundwater basin is necessary to adequately assess the transport of radionuclides moving toward Oasis Valley. Boundary flows were identified as one of the key uncertainties that required further investigation prior to a second phase of flow and transport numerical modeling activities (Stoller-Navarro Joint Venture, 2009). A more complete understanding of the total area contributing groundwater to the basin and of the boundaries that separate flow in the PMOV groundwater basin from adjacent basins will provide for future evaluation of environmental risks and remediation strategies.

\section{Description of Study Area}

The PMOV groundwater basin is in Nye County, southern Nevada. Oasis Valley is in the southern part of the basin and terminates near Beatty, Nevada (fig. 1). An extensive volcanic plateau (Pahute Mesa, Black Mountain, and Timber Mountain) covers most of the central part of the basin and several elongated mountain ranges (Kawich and Belted Ranges) and valleys (Gold Flat and Kawich Valley) are farther north. The eastern boundary of the PMOV groundwater basin is the Belted Range, whereas the western boundary is poorly defined, transitioning into Sarcobatus Flat near Black Mountain and Bullfrog Hills. Altitudes range from about 3,500 $\mathrm{ft}$ in Oasis Valley to about 8,300 $\mathrm{ft}$ in the Belted and Kawich Ranges. 


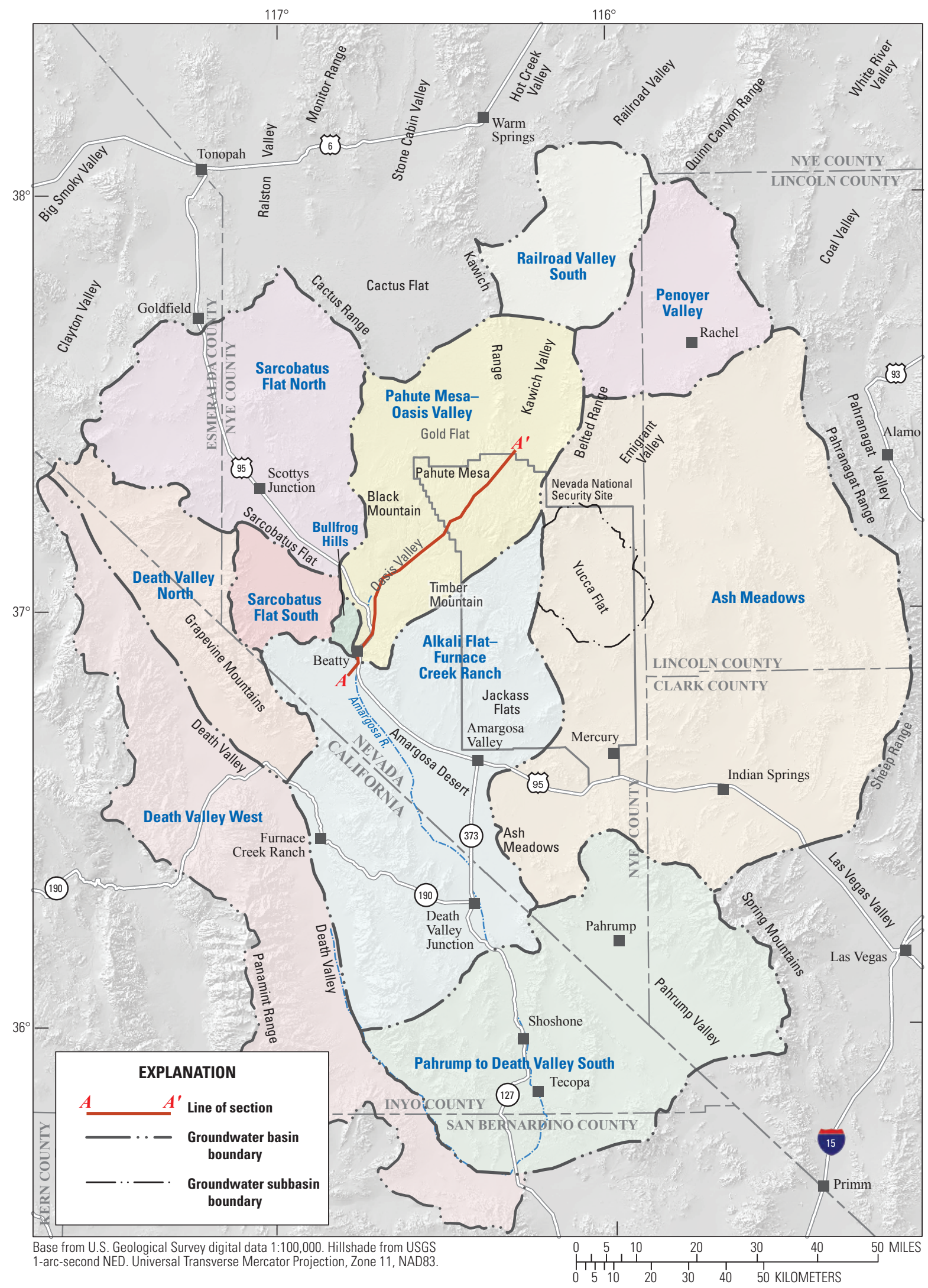

Figure 1. Geographic features and groundwater basins in the region surrounding the Pahute Mesa-Oasis Valley groundwater basin, Nevada and California. 
The climate of the study area is arid to semi-arid, characteristic of a high desert region. The climate is characterized by hot summers and mild winters, large fluctuations in daily and annual temperatures, and low precipitation and humidity. Average summertime maximum temperatures in Oasis Valley are nearly $100^{\circ} \mathrm{F}$ (National Climatic Data Center, 2013), and average wintertime minimum temperatures on Pahute Mesa are about $25^{\circ} \mathrm{F}$ (Soulé, 2006). Annual precipitation in the study area ranges from about 6 in. in Oasis Valley to about 8-13 in. on the upland areas (Soulé, 2006; National Climatic Data Center, 2013). Precipitation occurs primarily in late autumn through early spring and in mid-summer. Precipitation falls primarily as rain and as snow during the winter months at high altitudes. Streams in the study area are ephemeral and flow only for brief periods after infrequent intense rainfall and during and shortly after spring snowmelt. Perennial streamflow in the study area occurs only over short reaches of the Amargosa River downgradient of a few large springs in the Oasis Valley area.

\section{Hydrogeology}

The hydrogeologic framework of the study area is dominated by Miocene-age volcanic rocks of the southwestern Nevada volcanic field (Grauch and others, 1999). Multiple eruptions from at least six calderas centered on Pahute Mesa, Timber Mountain, and Black Mountain have produced volcanic deposits of lava and vast blankets of tuff that are more than 10,000 ft thick (fig. 2; Blankennagel and Weir, 1973; Sawyer and others, 1994; Bechtel Nevada, 2002). Deposits associated with the calderas include glassy and crystalline lava flows; air-fall, ash-flow, and reworked tuffs; and tectonic, eruptive, and flow breccias. The estimated volume of rock erupted from these calderas exceeds $3,000 \mathrm{mi}^{3}$ (Sawyer and others, 1994). Other rocks contributing to the hydrogeologic framework of the study area include locally thick (greater than 1,000 ft) Cenozoic basin-fill deposits, thrust blocks of Paleozoic carbonate rock, and sedimentary and metamorphic siliciclastic rocks of Proterozoic through Paleozoic age (Bechtel Nevada, 2002; Faunt and others, 2010). Mid-to-late Cenozoic extensional faulting resulted in northwest- to northeast-striking, high-angle normal faults with as much as $500 \mathrm{ft}$ of vertical offset on Pahute Mesa (McKee and others, 2001; Bechtel Nevada, 2002).

Because of the thickness of volcanic rocks underlying Pahute Mesa, these rocks form the principal aquifers and confining units in the area and are the primary control on the groundwater-flow system (Blankennagel and Weir, 1973; Fenelon and others, 2010). Rhyolite lavas and densely welded ash-flow tuffs are the principal volcanic aquifers. Rhyolite lavas can have high permeabilities where fractured, but the

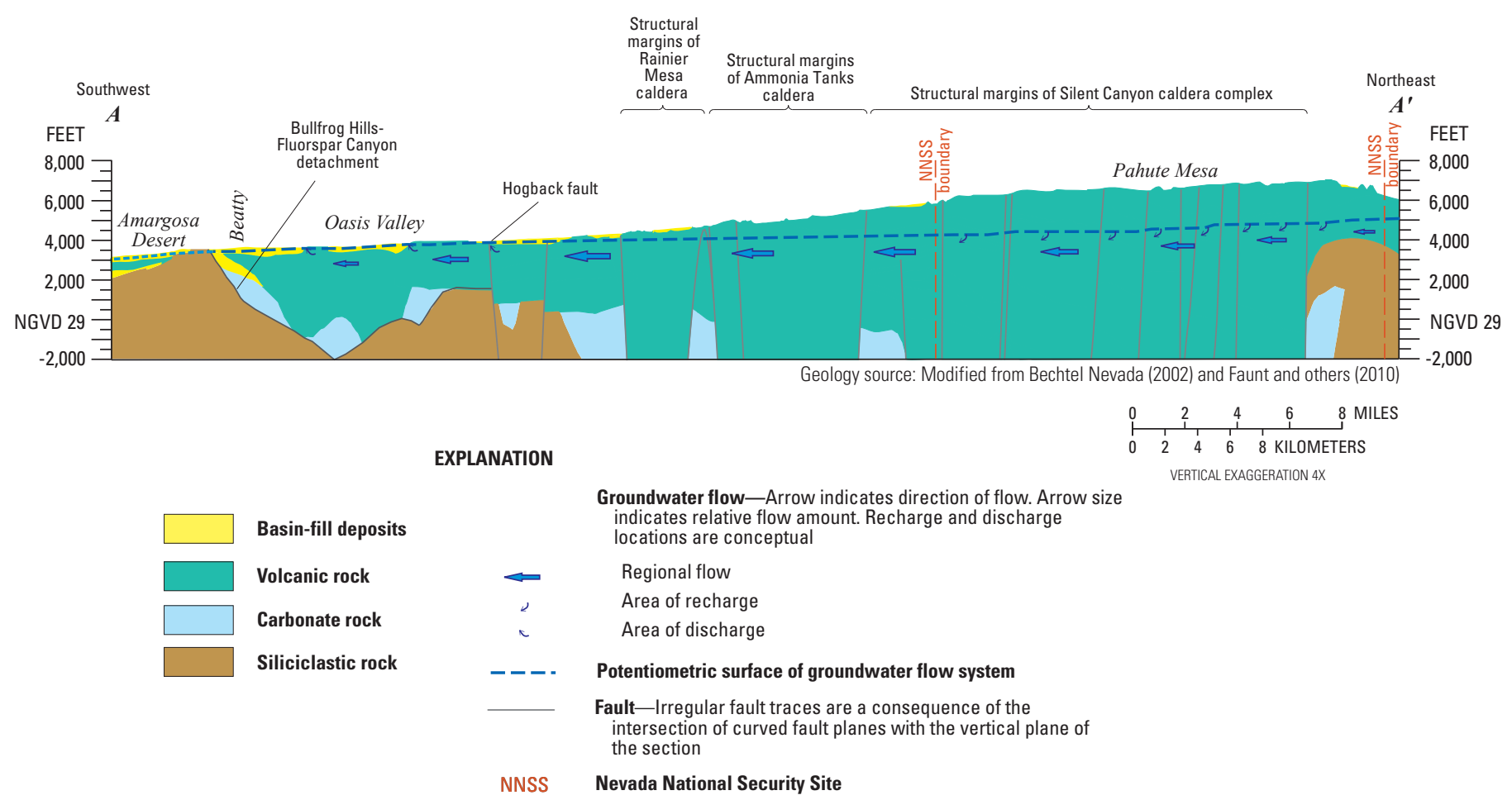

Figure 2. Hydrogeologic section from Pahute Mesa to Oasis Valley, Nevada (modified from Fenelon and others, 2010). Trace of section is shown in figure 1. 
lavas are restricted areally and in thickness (Prothro and Drellack, 1997). Densely welded ash-flow tuffs typically have well-connected fracture networks and are widespread, which can provide lateral continuity for water to move through the flow system. Groundwater flow is obstructed by low-permeability rock that forms confining units. Partially welded and nonwelded ash-flow and ash-fall tuffs have limited fracture networks and, as a result, typically are confining units, especially where they are zeolitized. In the Oasis Valley area, localized alluvial deposits and carbonate rocks (fig. 2) may provide local pathways for groundwater flow (White, 1979; Bechtel Nevada, 2002). North of the NNSS in Gold Flat and Kawich Valley, the saturated zone is dominated by pre-Cenozoic siliciclastic rocks and Cenozoic basin-filling sedimentary and volcanic rocks that underlie and pre-date the southwestern Nevada volcanic field (Faunt and others, 2010).

Recharge in the PMOV groundwater basin occurs on volcanic highlands such as Pahute Mesa (fig. 2) and Timber Mountain, and as infiltration of runoff from highlands onto alluvial fans. Most recharge occurs as precipitation collects in surface fractures and openings of permeable volcanic rocks and infiltrates downward by way of interconnected fractures or through the rock matrix to depths beyond the influence of evaporation and transpiration. A small amount of recharge occurs in highland areas composed of siliciclastic and other undifferentiated low-permeability rocks, such as the Kawich and Belted Ranges. In these areas, a minor amount of recharge will infiltrate locally but most of the precipitation is conceptualized to occur when water from snowmelt or highintensity rainfall runs off and infiltrates adjacent alluvial fans at lower elevations (Hevesi and others, 2003; Flint and others, 2004). Most recharge occurring in the PMOV groundwater basin replenishes the volcanic and alluvial aquifers in the basin.

Groundwater in the study area generally moves southsouthwest, under Pahute Mesa, toward springs and seeps in Oasis Valley (fig. 2), where greater than 98 percent of the total groundwater flow discharges (Reiner and others, 2002; Fenelon and others, 2010). Outflow from Oasis Valley is thought to be controlled by a deep confining unit of siliciclastic rocks, which underlies the southern part of the flow system and crops out near Oasis Valley (fig. 2; Reiner and others, 2002). The confining unit may force water upward through faults in the area (Laczniak and others, 1996). An estimated 5,900 acre-ft/yr of groundwater discharges to Oasis Valley, and an additional $100 \mathrm{acre-ft} / \mathrm{yr}$ discharges to upland springs and seeps in Bullfrog Hills (Reiner and others, 2002). Groundwater discharges from springs or by diffuse upward flow into an overlying shallow flow system where the water is evaporated, or transpired by phreatophytes. Subsurface outflow from Oasis Valley to the Amargosa Desert through alluvium in southern Oasis Valley is minor, and is estimated at about 100 acre-ft/yr (Reiner and others, 2002).
The PMOV groundwater basin is within the Death Valley groundwater flow system, one of the major hydrologic subdivisions of the southern Great Basin (Harrill and others, 1988). An estimated 90,000 acre-ft of groundwater flows through the Death Valley flow system annually (San Juan and others, 2010). The primary discharge areas for this flow, where natural (nonpumping) discharge exceeds 5,000 acre-ft/yr, are at Death Valley, Ash Meadows, Oasis Valley, Sarcobatus Flat, and near Tecopa and Shoshone; Pahrump Valley also was a major area of natural discharge prior to development (fig. 1). A small component of flow northeast of the PMOV groundwater basin may discharge to Penoyer Valley (Van Denburgh and Rush, 1974).

\section{Purpose and Scope}

The purpose of this report is to define the contributing area where recharge occurs, moves downgradient, and discharges to Oasis Valley. This area is referred to as the Pahute Mesa-Oasis Valley (PMOV) groundwater basin. The contributing area is defined with regional water-level contours, geologic controls, and knowledge of adjacent flow systems. The viability of this area as the contributing area to Oasis Valley and the absence of significant interbasin flow between the PMOV groundwater basin and adjacent basins are shown regionally and locally. Regional constraints on the location of the contributing area boundary and on the absence of interbasin groundwater flow are shown by balancing groundwater discharges in the PMOV groundwater basin and adjacent basins against recharge estimates. Internal consistency for the delineated contributing area is shown by matching measured water levels, groundwater discharges, and transmissivities with simulated results from a single-layer, steady-state, groundwater-flow model and by doing a simple chloride mass balance. Uncertainty in the delineated contributing area is addressed through alternative contributing areas and a discussion of the inadequacies of these alternatives.

\section{Delineation of the Pahute Mesa-0asis Valley Groundwater Basin}

The contributing area for the PMOV groundwater basin was defined using an iterative process, starting with a regional water budget analysis and followed by groundwater flow simulation of the basin (local-scale analysis). For the regional analysis, water levels and previously mapped basin extents were used to delineate the boundaries between the PMOV groundwater basin and adjacent bounding basins. Next, recharge was estimated for the PMOV and all bounding groundwater basins (pl. 1), and this recharge was compared to measured discharge for each basin. 
If a reasonable balance was achieved between basins (regional analysis), the delineated extent of the PMOV groundwater basin was used as a no-flow boundary for a one-layer groundwater-flow model to conduct a local-scale analysis. The flow model was calibrated using water levels, groundwater discharge, and field-estimated transmissivity to evaluate the delineated basin boundary. Inconsistencies between the regional analysis and groundwater-flow model were used to inform the next revision of the PMOV groundwater basin boundary.

Eight iterative adjustments were made to the boundary, with the final basin boundary presented in figures. Evaluation of the eight basin boundaries defined during the iterative process are described and discussed in the section, "Boundary Uncertainty."

\section{Regional Water-Budget Analysis}

The PMOV and adjacent groundwater basins were delineated using water-level contours, information from previous investigations, and comparisons of estimated recharge with measured discharge. Basin delineation required more than just water-level contours because water-level data are sparse in many areas and hydraulic gradients in most of the valleys are flat, making determination of groundwater divides difficult.

Basins surrounding the PMOV groundwater basin include Sarcobatus Flat (divided into northern and southern components), the southern part of Railroad Valley, Penoyer Valley, Ash Meadows, and Death Valley (fig. 1 and pl. 1). The Death Valley groundwater basin is divided into a western basin, Death Valley West, and three eastern basins: Death Valley North, centrally located Alkali Flat-Furnace Creek Ranch, and Pahrump to Death Valley South. Death Valley West groundwater basin extends from the Panamint Range eastward to the floor of Death Valley and includes all discharge occurring on the western side of Death Valley. Death Valley North groundwater basin includes discharge primarily in the areas of Mesquite Flat and Grapevine Springs on the northeastern side of Death Valley. Alkali Flat-Furnace Creek Ranch groundwater basin (fig. 1; Waddell, 1982) includes discharges to Franklin Well and Franklin Lake playa discharge areas and large springs and areas of phreatophytes near Furnace Creek Ranch (pl. 1; Laczniak and others, 2001). Death Valley South groundwater basin includes discharge primarily to the southeastern part of Death Valley, Tecopa and Shoshone discharge areas, and natural areas of discharge in Pahrump Valley that existed prior to agricultural development (pl. 1; San Juan and others, 2010).

Groundwater basin boundaries were drawn along groundwater divides or perpendicular to water-level contours (pl. 1). Water-level contours used to delineate basins were modified from U.S. Department of Energy (1997a) as follows: (1) contours in a few areas that were higher than land surface were adjusted so that they did not indicate flowing conditions, and (2) contours in the areas of the NNSS and PMOV groundwater basin were modified where additional data have been collected and interpreted (Elliot and Fenelon, 2010; Fenelon and others, 2010). Recharge and discharge areas in each basin, boundaries of hydrographic areas (Rush, 1968; Cardinalli and others, 1968), hydrogeologic framework, and previous studies also were used to define basin boundaries. Previous studies that were considered include Waddell (1982), Harrill and others (1988), Laczniak and others (1996), D'Agnese and others (1997, 2002), Bedinger and Harrill (2010), Belcher and Sweetkind (2010), and Heilweil and Brooks (2011). Hydrographic areas, as defined by Rush (1968), generally consist of valleys extending to surrounding surface-water drainage divides.

Most of the groundwater basin boundaries (pl. 1) represent no-flow boundaries. Although these basin boundaries may not be no-flow in an absolute sense, it is assumed that flow across the boundaries is negligible relative to the recharge-discharge basin balances. Most areas of interbasin groundwater flow were accounted for by extending a groundwater basin boundary to incorporate the areas of interbasin flow. For example, the Ash Meadows groundwater basin incorporates interbasin flow that occurs across eight hydrographic areas.

The few occurrences where interbasin flow crosses a delineated groundwater basin boundary are shown on plate 1 and are listed as follows:

1. At the southern tip of the PMOV groundwater basin, about 400 acre-ft/yr of water that originates in the basin flows into the Alkali Flat-Furnace Creek Ranch groundwater basin. About 100 acre-ft/yr of groundwater flows across the basin boundary through the alluvium underlying the Amargosa River (Reiner and others, 2002). An additional estimated 300 acre-ft/yr of surface water in the Amargosa River flows southward past U.S. Geological Survey (USGS) streamgage 10251217 (Amargosa River at Beatty, Nev.). This streamflow infiltrates the river channel and becomes groundwater in the Alkali Flat-Furnace Creek Ranch groundwater basin (Stonestrom and others, 2007; U.S. Geological Survey, 2015a).

2. Railroad Valley South groundwater basin is not closed. Of the estimated 5,200 acre- $\mathrm{ft} / \mathrm{yr}$ of recharge occurring there, only about 200 acre-ft/yr discharges locally (Van Denburgh and Rush, 1974). Most of the recharge flows north and discharges in the northern part of Railroad Valley (pl. 1; Van Denburgh and Rush, 1974; Harrill and others, 1988).

3. Interbasin flow from the Ash Meadows groundwater basin into the Alkali Flat-Furnace Creek Ranch groundwater basin occurs south of Amargosa Valley and north of Ash Meadows. This flow can be estimated using a simplified form of Darcy's law (Heath, 1983, p. 26), which is expressed as: 
Delineation of the Pahute Mesa-0asis Valley Groundwater Basin, Nevada

$$
Q=0.00838 T W(d h / d l)
$$

$$
\begin{array}{r}
\text { where } \\
Q \quad \begin{array}{r}
\text { is discharge, in acre-feet per year; } \\
\text { is transmissivity of the hydrologic units at the } \\
\text { basin boundary, in feet squared per day; }
\end{array} \\
W \quad \begin{array}{r}
\text { is length of the cross-sectional area through } \\
\text { which flow occurs, perpendicular to the } \\
\text { direction of flow, in feet; }
\end{array} \\
\begin{array}{c}
\text { is hydraulic gradient across the basin } \\
\text { boundary, in feet per foot; and }
\end{array} \\
\begin{array}{c}
\text { is the conversion factor to convert cubic feet } \\
\text { per day to acre-feet per year. }
\end{array}
\end{array}
$$

About 2,000 acre-ft/yr of discharge is estimated with equation 1, assuming a hydraulic gradient of $0.01 \mathrm{ft} / \mathrm{ft}$, a length of $11,000 \mathrm{ft}$ ( $2 \mathrm{mi}$ ), and a transmissivity of $2,000 \mathrm{ft}^{2} / \mathrm{d}$. The gradient from Ash Meadows into the Alkali Flat-Furnace Creek Ranch groundwater basin was estimated from water levels in wells shown on plate 1; the length is parallel to the basin boundary, as delineated on plate 1; and the transmissivity was estimated from specific-capacity tests in the basin fill immediately west and south of the interbasin groundwater flow arrow shown on plate 1 . Specific-capacity tests were derived from well logs (log numbers 6069, 6115, 7474, 7193, 8040, and 25462) reported in Nevada Division of Water Resources (2015). The estimated discharge of 2,000 acre-ft/yr is uncertain because of uncertainty in the transmissivity estimate and the length of the cross-sectional area.

4. A water-level mound beneath the Panamint Range is assumed to form a groundwater divide that forms a barrier to flow beneath the range. Contrarily, Bedinger and Harrill (2010) conceptualized that groundwater derived from west of the Panamint Range flows under the range and discharges into Death Valley. This scenario is unlikely because it does not allow for a groundwater mound to exist on the Panamint Range, even though the range is underlain primarily by crystalline-rock confining units and has a high rate of recharge.

\section{Groundwater Discharge Estimates}

Of the three main components (discharge, recharge, and groundwater flow) of a groundwater budget for an undeveloped area, groundwater discharge typically is the simplest and most direct component to measure (Bredehoeft, 2007). Recharge and groundwater flow rates are more difficult to measure, so reliable estimates of groundwater discharge can constrain the other, more-difficult-to-quantify components of the water budget.

Groundwater discharges naturally in topographically low areas where groundwater is at or near land surface by three processes: (1) spring flow and seepage, (2) transpiration by local phreatophytic vegetation, and (3) evaporation from soil and open water. Each of these processes can be measured directly. As groundwater emerges from springs, it forms ponds or flows into free-flowing drainages or local reservoirs. Some of this water infiltrates downward into soils and possibly into an underlying shallow aquifer, but most of the water ultimately is consumed by phreatophytic vegetation or is evaporated. The combined processes of evaporation and transpiration are referred to as evapotranspiration (ET). Spring locations and areas of ET are shown on plate 1.

The amount and rate of water lost to the atmosphere by ET from groundwater discharge areas vary with vegetation type and density, and soil characteristics (Laczniak and others, 1999, 2001, 2008; Reiner and others, 2002; DeMeo and others, 2003; Moreo and others, 2007; Allander and others, 2009).

Recent studies in Nevada have applied various remote-sensing techniques using satellite imagery in combination with field mapping and ET measurements to identify and group areas of similar vegetation and soil conditions within groundwater discharge areas (Smith and others, 2007; Allander and others, 2009; Garcia and others, 2014, D.L. Berger, U.S. Geological Survey, written commun., 2015). Vegetation and soil groupings are referred to as ET units because they represent areas with similar ET rates. Typical ET units include areas of no vegetation, such as open water, dry playa, and moist bare soil, and areas with vegetation dominated by phreatophytic shrubs, grasses, rushes, and reeds.

Regional groundwater discharge is estimated by identifying ET units across a study area, measuring the total ET from all units, and subtracting non-groundwater contributions such as local precipitation. Local precipitation is assumed to evaporate locally or supply plant needs when available. The resultant ET that is contributed by groundwater is referred to as GWET.

Predevelopment groundwater discharge was estimated for each groundwater basin (table 1; fig. 3). Estimates consisted of existing (Hunt and others, 1966; Malmberg, 1967; Rush, 1970; Rush and Van Denburgh, 1974; Harrill, 1986; Laczniak and others, 1999; 2001; 2006; Reiner and others, 2002; and DeMeo and others, 2003) and re-estimated (appendix A) values within each basin. Some estimates, such as for Ash Meadows (Laczniak and others, 1999) and Oasis Valley (Reiner and others, 2002), are reasonably certain because of detailed, site-specific, field studies (fig. 3). Uncertainty as a percentage of total discharge is greater where groundwater discharge rates are extrapolated for a basin based on ET rates from another basin. Rates were extrapolated for discharge areas in Sarcobatus Flat North and South, Railroad Valley South, Penoyer Valley, and for most of the discharge areas in Pahrump to Death Valley South. Uncertainty in discharge is especially high for Death Valley South groundwater basin. About one-half of the predevelopment flow for this basin occurs in Pahrump Valley, where the groundwater system has been extensively altered because of groundwater pumping. 
Table 1. Discharge areas and annual predevelopment discharge rates for Pahute Mesa-Oasis Valley and surrounding groundwater basins, Nevada and California.

[Locations of groundwater basins are shown on plate 1. Abbreviations: PMOV, Pahute Mesa-Oasis Valley; acre-ft/yr, acre-foot per year; ft/d, foot per day. Discharge rates rounded to nearest 100 acre-feet. Totals may not add up due to rounding]

\begin{tabular}{|c|c|c|c|}
\hline Groundwater basin & Discharge area & $\begin{array}{l}\text { Predevelopment } \\
\text { discharge rate } \\
\text { (acre-ft/yr) }\end{array}$ & Source for rate \\
\hline PMOV & Oasis Valley $^{1}$ & 5,900 & Reiner and others, 2002 \\
\hline PMOV & Total & 5,900 & \\
\hline Bullfrog Hills & Total & 100 & Reiner and others, 2002 \\
\hline Sarcobatus Flat North & Total & 5,600 & This study; Laczniak and others, 2001 \\
\hline Sarcobatus Flat South & Total & 1,900 & This study; Laczniak and others, 2001 \\
\hline \multirow[t]{2}{*}{ Death Valley North } & Death Valley floor, northeast ${ }^{2}$ & 3,200 & This study; DeMeo and others, 2003 \\
\hline & Grapevine Springs area & 790 & Laczniak and others, 2006 \\
\hline Death Valley North & Total & 4,000 & \\
\hline \multirow[t]{5}{*}{ Alkali Flat-Furnace Creek Ranch } & Franklin Lake playa & 1,000 & Laczniak and others, 2001 \\
\hline & Franklin Well area & 340 & Laczniak and others, 2001 \\
\hline & Death Valley floor, east-central ${ }^{2}$ & 4,000 & This study; DeMeo and others, 2003 \\
\hline & Furnace Creek springs & 2,300 & San Juan and others, 2010 \\
\hline & Saltpan run-on & 240 & Hunt and others (1966) \\
\hline Alkali Flat-Furnace Creek Ranch & Total & 7,900 & \\
\hline \multirow[t]{6}{*}{ Pahrump to Death Valley South } & Pahrump Valley & 13,000 & Harrill, 1986 \\
\hline & Stewart Valley & 1,000 & San Juan and others, 2010 \\
\hline & Chicago Valley & 430 & San Juan and others, 2010 \\
\hline & Tecopa/California Valley area & 6,400 & San Juan and others, 2010 \\
\hline & Shoshone area & 2,100 & San Juan and others, 2010 \\
\hline & Death Valley floor, southeast ${ }^{2}$ & 2,300 & This study; DeMeo and others, 2003 \\
\hline Pahrump to Death Valley South & Total & 25,200 & \\
\hline \multirow[t]{2}{*}{ Death Valley West } & Death Valley floor, west ${ }^{2}$ & 12,500 & This study; DeMeo and others, 2003 \\
\hline & Saltpan run-on ${ }^{3}$ & 1,100 & Hunt and others (1966) \\
\hline Death Valley West & Total & 13,600 & \\
\hline Railroad Valley South & Total & 200 & Van Denburgh and Rush, 1974 \\
\hline Penoyer Valley & Total & 3,800 & Van Denburgh and Rush, 1974 \\
\hline \multirow[t]{3}{*}{ Ash Meadows } & Ash Meadows & 18,000 & Laczniak and others, 1999 \\
\hline & Yucca Flat subbasin & {$[1,000]^{4}$} & This study \\
\hline & Indian Springs Valley & 500 & Rush, 1970 \\
\hline Ash Meadows & Total & 18,500 & \\
\hline
\end{tabular}

\footnotetext{
${ }^{1}$ Does not include discharge to springs in Bullfrog Hills.

${ }^{2}$ Estimate includes groundwater evapotranspiration from vegetated areas and groundwater evaporation from playa deposits. Groundwater evaporation rates used to calculate discharge are 0.01 and $0.005 \mathrm{ft} / \mathrm{d}$ for the bare-soil playa and salt-encrusted playa, respectively.

${ }^{3}$ Base flow from Salt Creek that runs onto salt playa and evaporates.

${ }^{4}$ Included in Ash Meadows discharge rate. Number in brackets is not included in total discharge from groundwater basin.
} 


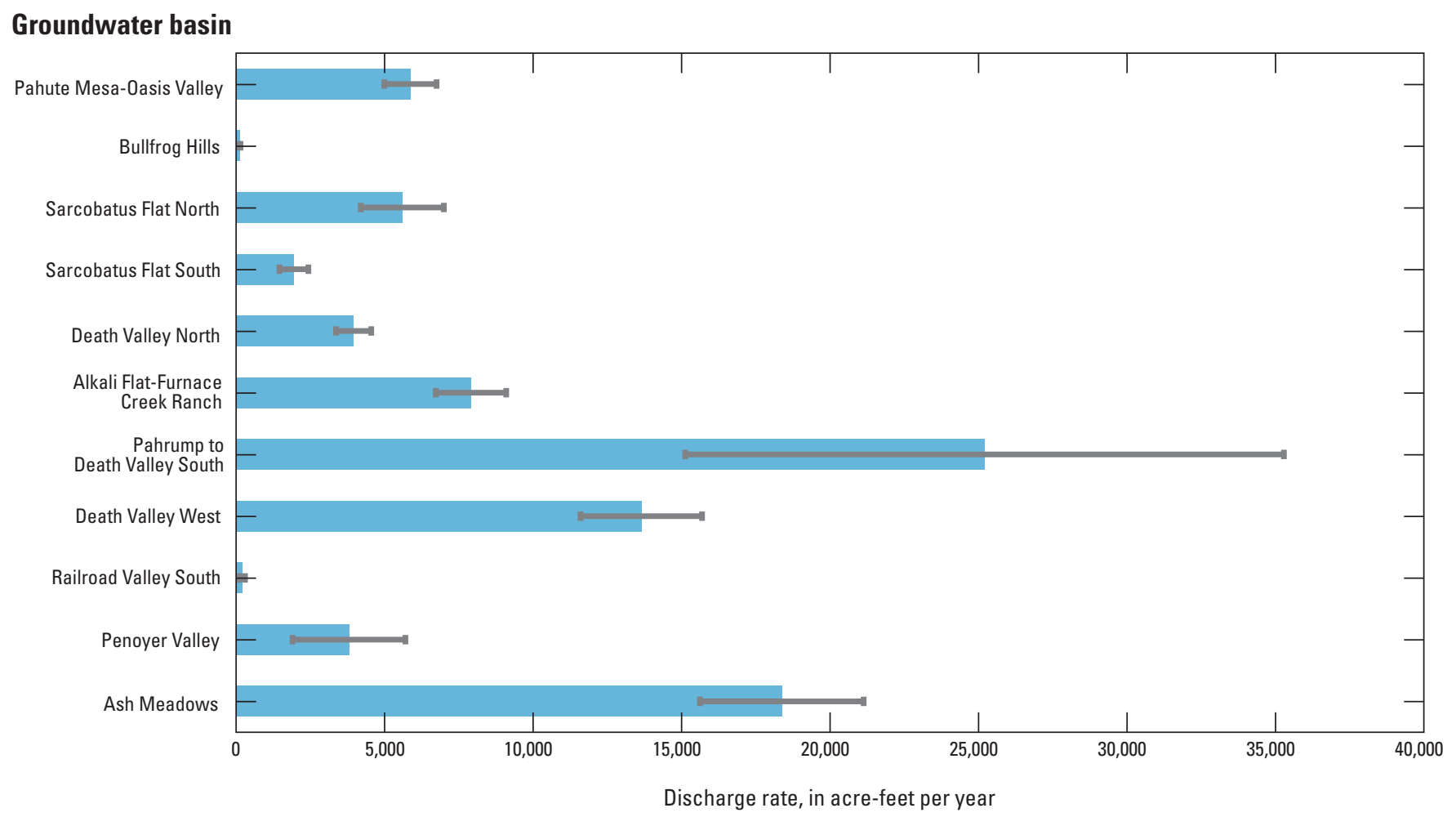

Figure 3. Annual predevelopment groundwater discharge rates for Pahute Mesa-Oasis Valley and surrounding groundwater basins, Nevada and California. Error bars represent uncertainty in groundwater discharge estimates.

Discharge estimates for Pahrump Valley are based on historical spring measurements and phreatophyte distributions that may be diminished by pumping (Harrill, 1986). Studies of groundwater discharge estimates for all groundwater basins were critically evaluated, and discharge rates were recomputed where new data conflicted with published rates. Discharge rates for playa ET units in Death Valley and the sparse to moderately dense shrubland ET unit in Sarcobatus Flat were re-estimated for this study and are discussed in appendix A.

\section{Recharge Estimates}

Recharge was estimated using three methods: (1) the modified Maxey-Eakin method, (2) a soil-water balance method known as the INFILv3 model, and (3) a second soil-water balance method known as the Basin Characterization Model (BCM).

The simplest approach was to divide the area based on ranges of precipitation rates, and scale precipitation within each range to balance estimated groundwater discharge. This method, known as the modified Maxey-Eakin method, is discussed in more detail in the section, "Boundary Uncertainty." The other two methods used published recharge distributions from two regional soil-water balance models. Recharge estimates from the soil-water balance models were subsequently scaled to balance discharge as reported in table 1.
Regional recharge was estimated by the modified Maxey-Eakin method using a distribution of mean annual precipitation from 1981 to 2010 . The precipitation distribution was derived from published Parameter-elevation Regressions on Independent Slopes Model (PRISM) results that used a 30-arcsec (approximately 800-m) grid resolution (PRISM Climate Group, 2012). PRISM is a regression-based model of the conterminous United States that interpolates between precipitation measurements and accounts for physiographically complex landscapes using an 80-m DigitalElevation Model (DEM) (Daly and others, 2008).

Soil-water balance models simulate precipitation-driven runoff, accumulation of water in the soil, evapotranspiration of some of the soil moisture, and deep infiltration of the remaining soil water. Deep infiltration to groundwater (recharge) is leakage from the bottom of the soil zone, below which ET is assumed to be negligible. The deep infiltration rate is simulated as a function of soil moisture and vertical leakance. Vertical leakance is estimated indirectly from soil maps and surface geology. Recharge also occurs during runoff, primarily as infiltration through ephemeral stream channels. This runoff-driven recharge was assumed to be 15 percent of the total runoff for a study in east-central Nevada (Flint and Flint, 2007). Total groundwater recharge is the sum of the deep infiltration from the soil-water balance model and the ephemeral stream recharge. 
Recharge was estimated using the soil-water balance model, INFILv3 (U.S. Geological Survey, 2008), which was constructed for use in the Death Valley regional flow system (Hevesi and others, 2003). Net infiltration includes local infiltration and infiltration of runoff from upgradient cells. INFILv3 spatially and temporally quantifies the amount of water infiltrating below the root zone, which is assumed equal to recharge at the water table. The INFILv3 model estimates the daily water balance of the root zone by accounting for many parameters including precipitation, snowmelt, evapotranspiration, water-content change, surface-water runoff and run-on, and net infiltration. The model uses daily climate records and accounts for topography, geology, soils, and vegetation.

The second soil-water balance method of estimating recharge used the Basin Characterization Model (BCM), a distributed-parameter water-balance model (Flint and Flint, 2007; Flint and others, 2010). The BCM encompasses the Basin and Range Physiographic Province in the eastern two-thirds of Nevada and western one-third of Utah. Like INFILv3, the BCM estimates net infiltration using a soil-water balance, but runoff is accumulated and empirically applied in-place on a monthly time scale.

\section{Groundwater Basin Flow Balances}

Discharge rates for the groundwater basins (pl. 1; table 1) were balanced against recharge rates. More than one recharge estimation method was investigated to determine whether the recharge estimate affected the balance.

During the initial basin-balance analyses, basins incorporating Sarcobatus Flat (Sarcobatus Flat North and South) and Death Valley (Alkali Flat-Furnace Creek Ranch, and Death Valley North, South, and West) indicated an excess of discharge relative to recharge. Upon further analysis, it was determined that the published discharge rates (Laczniak and others, 2001; DeMeo and others, 2003) likely were overestimated for these basins. Discharge rates were re-evaluated for this study and are discussed in appendix A.

Several of the groundwater basins or subbasins were included in the basin balance models but were not used in the fitting process to determine the best balance of recharge and discharge. These included Railroad Valley South, Death Valley West, and Bullfrog Hills groundwater basins and Yucca Flat subbasin. Most of the recharge generated in southern Railroad Valley probably flows north and discharges in the main part of Railroad Valley to the north (Van Denburgh and Rush, 1974). Because Railroad Valley South is not a closed groundwater basin, it was not included in the balance. Bullfrog Hills and Yucca Flat receive most recharge water from relatively low-lying areas. These basins were not used in the balance because they are small areas with low precipitation, and the basin-balance method is designed to estimate average recharge across the region. Bullfrog Hills groundwater basin and Yucca Flat subbasin were included in the basin-balance model only as a check to ensure that areas with minor precipitation could provide sufficient recharge to supply the measured discharge in their respective basins. Death Valley West groundwater basin was included in the basin-balance model because discharge data are available for this basin and it provided an independent measure of how well the model performed. The Death Valley West basin was not used to determine the balance, however, because it is distant and hydraulically isolated from the PMOV groundwater basin.

\section{Modified Maxey-Eakin Method}

Recharge was estimated from the PRISM precipitation distribution that was scaled to match measured discharge (table 1). The approach used an empirical basin-balance method analogous to the Maxey-Eakin method (Maxey and Eakin, 1951; Avon and Durbin, 1994). The method simultaneously balances estimates of recharge with discharge in all basins. Recharge rates are estimated by multiplying annual precipitation amounts within specified precipitation ranges by coefficients that represent the fraction of precipitation that is converted to recharge. Precipitation for the area within each range is summed by groundwater basin and multiplied by a fitted coefficient to estimate precipitationderived recharge. Recharge is balanced against discharge simultaneously within each basin by varying the coefficients for each precipitation range to get a best fit (appendix B). A rule was applied that requires a precipitation range with a higher precipitation rate to have a coefficient that is equal to or greater than a range with a lower rate. This was done because it is assumed that as precipitation increases, a larger percentage is available for recharge. The best fit is measured by minimizing the root mean square (RMS) error of the differences between discharge and recharge in each groundwater basin using the Microsoft Excel ${ }^{\circledR}$ Solver. A best fit is obtained by manually changing the precipitation ranges, iteratively balancing recharge and discharge, and comparing RMS errors between models with different ranges until the error is minimized. A groundwater basin balance with an RMS error of about 2,000 acre-ft/yr is considered reasonable, given the uncertainties in recharge, discharge, and basin boundaries.

The best fit had an RMS error of 1,300 acre-ft/yr and required only two precipitation ranges: $0.4-1.6$ and $1.6-2.6 \mathrm{ft} / \mathrm{yr}$ (fig. 4). The fitting error is considered acceptable relative to the uncertainties in the PRISM precipitation distribution, discharge estimates (fig. 3), and delineation of groundwater basins (pl. 1). The area with the low-precipitation range had 0.8 percent of precipitation converted to recharge, whereas the area with the high range had 33 percent of precipitation converted to recharge. The high-range area occurred only in the Spring Mountains and affected Pahrump to Death Valley South and Ash Meadows groundwater basins. 


\section{Groundwater basin}

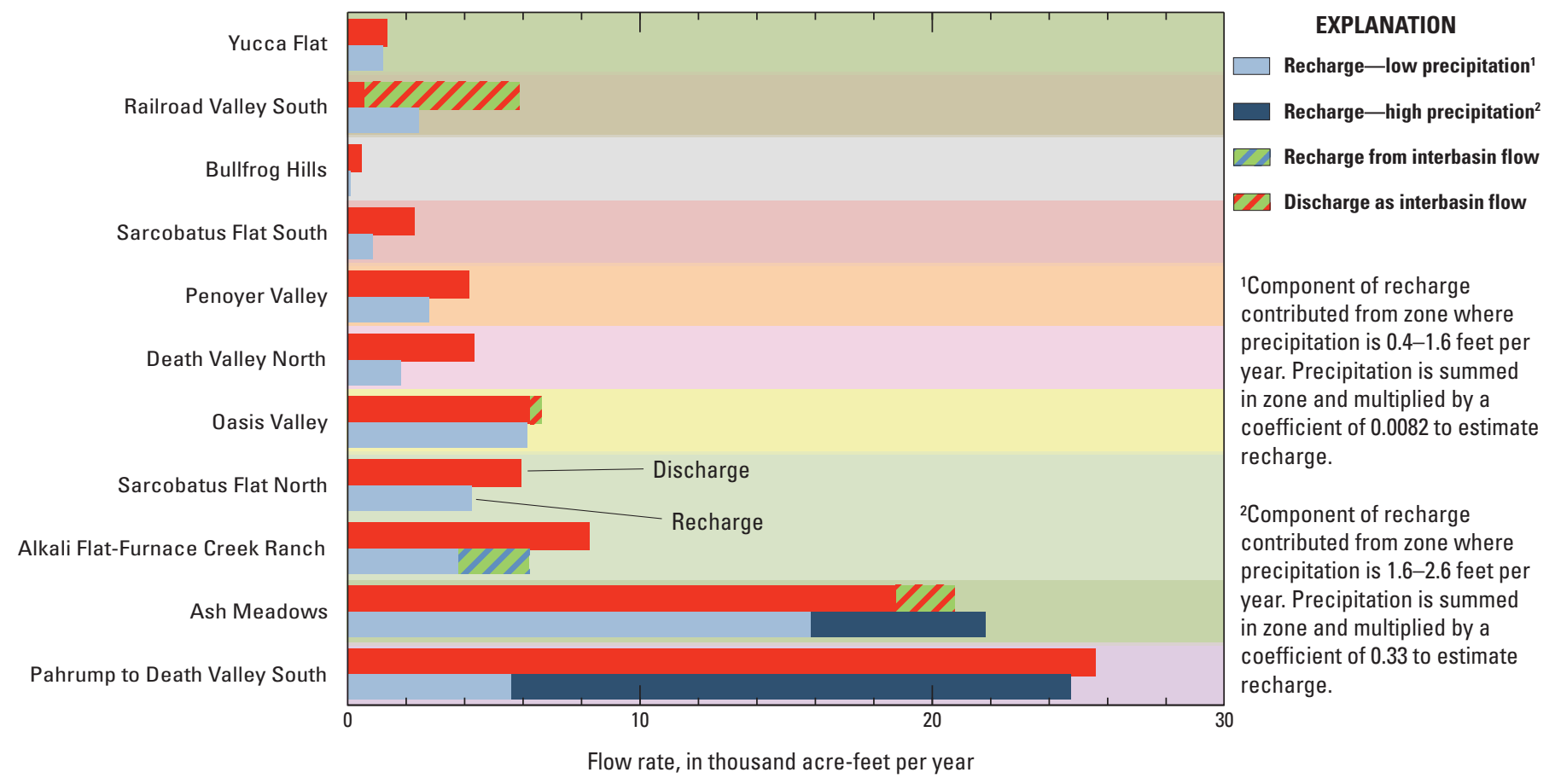

Figure 4. Comparison of simulated recharge with measured discharge using the modified Maxey-Eakin method with two recharge ranges for Pahute Mesa-Oasis Valley and surrounding groundwater basins or subbasins, Nevada and California. See appendix B for details of the analysis.

A rate of $0.4 \mathrm{ft} / \mathrm{yr}$ was specified for the lower end of the range of precipitation contributing to recharge, whereas Maxey and Eakin (1951) used a lower threshold of $0.67 \mathrm{ft} / \mathrm{yr}$ ( $8 \mathrm{in} / \mathrm{yr}$ ). A threshold of $0.4 \mathrm{ft} / \mathrm{yr}$ was used for the modified Maxey-Eakin method because groundwater discharge from Bullfrog Hills groundwater basin and Yucca Flat subbasin could not be balanced using the higher Maxey and Eakin (1951) threshold rate. Groundwater discharge from the Bullfrog Hills groundwater basin is estimated at about $100 \mathrm{acre}-\mathrm{ft} / \mathrm{yr}$ (table 1) and occurs in upland springs where water levels are more than $200 \mathrm{ft}$ higher than in adjacent Oasis Valley (White, 1979; Reiner and others, 2002). Maximum precipitation rates in the Bullfrog Hills groundwater basin are $0.6 \mathrm{ft} / \mathrm{yr}$. Therefore, recharge must occur locally in this basin and be derived from precipitation rates of less than $0.6 \mathrm{ft} / \mathrm{yr}$. Similarly, Yucca Flat subbasin discharges about $1,000 \mathrm{acre}-\mathrm{ft} / \mathrm{yr}$ to the downgradient end of the Ash Meadows groundwater basin (Harrill and others, 1988), and 80 percent of the precipitation occurs at rates of less than $0.67 \mathrm{ft} / \mathrm{yr}$. Greater imbalances between recharge and discharge in the Yucca Flat subbasin were observed when a threshold of $0.67 \mathrm{ft} / \mathrm{yr}$ was specified.

Because of high ET rates, the occurrence of recharge in areas receiving less than $0.5 \mathrm{ft} / \mathrm{yr}$ of precipitation requires focusing precipitation into washes during infrequent, high-intensity storms. Conceptually, this may be possible if large storms occurring every few years create episodic pulses of recharge in stream channels. Alternatively, it is possible that the basin-balance model is insensitive to where recharge occurs at the lower end of the precipitation range.

Death Valley West has a large discrepancy in its balance, with about 3.5 times more estimated discharge than recharge (13,600 compared to 3,900 acre-ft/yr; appendix B). Possible reasons for the poor fit are (1) an overestimate of the discharge on the floor of Death Valley (ET areas in Death Valley; pl. 1), (2) significant interbasin flow beneath the Panamint Range from farther west that was not accounted for in the balance, or (3) an underestimate of PRISM-derived precipitation in the Panamint Range. The first reason is unlikely because uncertainty in discharge from Death Valley West is estimated at about $\pm 2,000$ acre-ft/yr (fig. 3) and could not account for the $9,700 \mathrm{acre}-\mathrm{ft} / \mathrm{yr}$ balance deficit. The second reason, interbasin flow beneath the Panamint Range into Death Valley, is not likely because a recharge mound probably exists under the range as evidenced by multiple elevated springs (Bedinger and Harrill, 2010) and much of the range is underlain by siliciclastic rocks that are classified as confining units (Sweetkind and others, 2010). The third reason is most likely. PRISM is used to estimate precipitation for the conterminous United States. Precipitation estimation errors of 10 to greater than 30 percent are common in the mountainous western United States and are greatest where data are sparse (Daly and others, 2008). Precipitation errors may be high in the Panamint Range because there are no high-altitude precipitation stations 
from which to interpolate. The Spring Mountains, which have multiple precipitation stations, are comparable in size to the Panamint Range - both rise to more than $11,000 \mathrm{ft}$ in altitude. However, the PRISM-derived maximum precipitation rate for the Spring Mountains is $31 \mathrm{in} / \mathrm{yr}$, whereas the maximum rate for the Panamint Range is only $20 \mathrm{in} / \mathrm{yr}$. A 30-percent increase in the precipitation rate to the Panamint Range would account for the recharge deficit of 9,700 acre-ft/yr that was seen in the basin balance for Death Valley West.

\section{Distributed-Parameter, Deterministic Watershed Model (INFILv3)}

Recharge data derived from the INFILv3 model for the Death Valley regional flow system (Hevesi, 2006) were balanced simultaneously against discharge rates (table 1) for the groundwater basins delineated on plate 1 . The relative distribution of INFILv3 recharge was assumed correct, as published, but the absolute amount was allowed to be scaled up or down during the balancing analysis. The best fit used a multiplier of 0.9 ; that is, 90 percent of the recharge in the original data set was required to get a balance. The overall balance using the INFILv3 recharge data set was significantly worse than the balance from the modified Maxey-Eakin method (appendix B). The RMS error for INFILv3 was 4,200 acre-ft/yr, as compared to 1,300 acre-ft/yr for PRISM. An acceptable target error is about 2,000 acre-ft/yr.

\section{Basin Characterization Model}

Recharge data derived from the Basin Characterization Model (BCM) (Heilweil and Brooks, 2011) were investigated as an alternative recharge data set for balancing flow in the groundwater basins. Simple scaling of the recharge data set with a single multiplier, as was done for the INFILv3 data set, did not work because the relative amounts of recharge are grossly incorrect. For example, the Ash Meadows groundwater basin has about three times the discharge of the PMOV groundwater basin (table 1). Discharge estimates for these two areas are relatively certain (fig. 3), as they both had detailed, field-intensive evapotranspiration studies to estimate the discharge (Laczniak and others, 1999; Reiner and others, 2002). Contrarily, the Ash Meadows groundwater basin, as delineated on plate 1, has less BCM recharge than the PMOV groundwater basin. The poor balance between discharge and BCM-derived recharge at the sub-regional flow system scale was noted by Masbruch and others (2011, p. 90). Because of these large imbalances, the BCM data set does not represent a plausible recharge distribution for the area analyzed for the regional water-balance analysis.

\section{Comparison and Conclusions}

The results from the regional basin water-balance analysis are not meant to be definitive or to imply the exact distribution of recharge or the precise percentages of precipitation that contribute to recharge. Rather, the intent is to show that with reasonable groundwater basin delineations, there is sufficient internally derived recharge to supply the discharge occurring within a basin. Relatively large uncertainties in some of the basin discharge estimates (fig. 3) meant that the water-balance analysis was sufficient to determine only gross imbalances. The analysis also shows that the water balance in the PMOV groundwater basin is constrained by balances in adjacent groundwater basins. Each of the basins requires sufficient recharge water to supply discharge areas. By addressing all groundwater basins simultaneously, the water-balance method is able to account for the needs of adjacent basins when defining basin boundaries. The method also shows that sufficient water for Oasis Valley can reasonably be recharged within the delineated boundary and that interbasin flow from outside the PMOV groundwater basin boundary is not necessary to balance flow, nor is significant interbasin flow likely as has been suggested by other investigators (for example, Rose and Davisson, 2003).

In a regional analysis, there is no advantage to using the more computationally intensive INFILv3 or BCM model over the modified Maxey-Eakin approach that uses a simpler precipitation model such as PRISM. In fact, the basin balance obtained using the Maxey-Eakin approach was superior to the poor fit achieved with the INFILv3 recharge estimates and the gross imbalance using the BCM results. It is possible that INFILv3 is advantageous on a local scale for spatially distributing recharge. This is because INFILv3 accounts for many local variables affecting infiltration, such as land slope and geology. However, when recharge is summed over large groundwater basins, such as was done in the basin-balance analyses, the local variability of recharge provided from the INFILv3 model does not improve the regional estimates of recharge.

The average recharge rate for the delineated basins shown on plate 1 is $0.1 \mathrm{in} / \mathrm{yr}$ if recharge from the modified Maxey-Eakin approach is summed for these basins and divided by the total area. This average recharge rate equates to 1.3 percent of the average PRISM precipitation rate.

\section{Local-Scale Analysis}

The regional analysis defines a PMOV groundwater basin boundary that is defensible from a regional perspective and that honors boundaries and discharge amounts in adjacent groundwater basins. The local-scale analysis ensures that groundwater data from the PMOV groundwater basin are internally consistent with the regionally defined basin boundary. Internal consistency was tested by calibrating a numerical model of groundwater flow to water-level, landsurface, transmissivity, and discharge observations in the PMOV groundwater basin. Estimated recharge rates and transmissivities in the numerical model also were constrained to expected values from the conceptual model. 


\section{Model Construction}

A single-layer, groundwater-flow model was constructed to simulate steady-state water levels within the delineated PMOV groundwater basin boundary (fig. 5). The PMOV flow model is divided areally into 308 rows and 217 columns of uniform, square cells that are $300 \mathrm{~m}$ (984 ft) on a side. The model grid is oriented north-south in Universal Transverse Mercator (UTM), zone 11, North American Datum of 1983 (NAD 83) projection for convenience, and the coordinates of the northwest corner are 516500, 4174600. A unit thickness of $1 \mathrm{ft}$ was specified throughout the PMOV flow model because transmissivity was estimated. Groundwater-flow equations were solved using the USGS finite-difference model, MODFLOW (Harbaugh and others, 2000). The PMOV model was calibrated using the Parameter ESTimation code (PEST; Doherty, 2010a). Archives of the PMOV flow model containing executables, PEST calibration files, the steady-state model, and folders for drawing maps, creating MODFLOW packages, and simulating groundwater flow paths and velocities are available in Halford (2016; http://dx.doi. org/10.5066/F7N58JFQ).

The PMOV flow model conceptually extends from the water table to the base of the aquifer system. Specific thicknesses of the aquifer system were not defined, but flow logs and aquifer-test results suggest that most groundwater flow occurs in the upper 2,000 ft of saturated material (Garcia and others, 2010; Jackson and others, 2014).

Lateral boundaries are simulated as no-flow. The only exception is a single specified head in the southernmost cell of the Oasis Valley discharge area (near the 3,161-ft water-level measurement; fig. 5). This boundary simulates subsurface discharge from Oasis Valley to Amargosa Desert through a narrow section of saturated alluvium (Reiner and others, 2002). The single, specified-head cell also establishes a reference water level and balances small differences between specified recharge and discharge.

The 5,900 acre-ft/yr of discharge from the PMOV groundwater basin (table 1) was simulated as specified discharges in the PMOV flow model (fig. 5) using the well package in MODFLOW (Harbaugh and others, 2000). The distribution of discharge was defined using the maps of groundwater discharge rate by ET unit (GWET) created by Reiner and others (2002). Specified discharge within a model cell equals the sum of the ET unit areas in each cell multiplied by their respective groundwater discharge rates.

Discrepancies exist between actual and simulated discharge locations and rates because groundwater discharge was distributed with satellite imagery. Discrepancies are greatest at springs because water discharges at a discrete location and evapotranspires from a relatively large area downgradient of a spring orifice. Areas of evapotranspiration typically were about $1,000 \mathrm{ft}$ wide and extended less than $3,000 \mathrm{ft}$ below springs. Discrepancies in discharge locations and rates of discharge were ignored because corrections

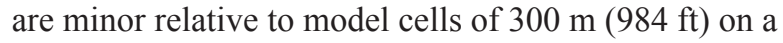

side. Discrepancies between actual and simulated discharge from phreatophytes and seeps are relatively minor because groundwater discharges diffusely and evapotranspires in place.

Transmissivity was estimated at pilot points, which are points in the model domain where simulated transmissivities are assigned (RamaRao and others, 1995). A transmissivity distribution was obtained by spatially interpolating pilot-point transmissivities across the model domain. Transmissivity pilot points were assigned at 295 locations, with a denser spacing of pilot points in the northwestern part of the NNSS and in the groundwater-discharge areas (fig. 6). Hydraulic properties were interpolated from transmissivity pilot points with kriging to node locations in the groundwater-flow model (Doherty, 2010b). Spatial variability of log-transmissivity was defined with an isotropic, exponential variogram, where nugget and range were 0 and $30,000 \mathrm{ft}$, respectively.

A recharge distribution was estimated for the PMOV model based on a conceptual model that areas with higher precipitation rates have higher recharge rates and precipitation falling on low-permeability rocks moves laterally until it can infiltrate more permeable materials. The recharge distribution, as defined by the modified Maxey-Eakin method, was not used because this method is a simple weighting scheme that is intended only to provide gross water balances between basins. The method has been applied successfully for many decades in Nevada as a basin-balance method and to determine basinwide recharge estimates. However, determining the local distribution of recharge within an individual basin requires a different approach. As with the modified Maxey-Eakin method, the total annual recharge for the PMOV model is consistent with the annual discharge of 5,900 acre-ft/yr to Oasis Valley.

Distributed recharge is conceptualized as a piece-wise linear function of total annual precipitation, as defined by the 1981-2010 distribution of precipitation in PRISM (PRISM Climate Group, 2012). A two-stage relation between precipitation and total potential recharge (infiltration and runoff recharge) is assumed. The water available for recharge was estimated from precipitation in excess of $0.4 \mathrm{ft} / \mathrm{yr}$, consistent with the modified Maxey-Eakin method. From 0.4 to $1 \mathrm{ft} / \mathrm{yr}$, the proportion of recharge increases from 0 to 1 percent of the annual precipitation (fig. $7 A$ ). For more than $1 \mathrm{ft}$ of annual precipitation, the slope of the function increases more than tenfold, so that about 7 percent of precipitation is converted to recharge at a precipitation rate of $1.5 \mathrm{ft} / \mathrm{yr}$. The selection of $1 \mathrm{ft} / \mathrm{yr}$ as an inflection point for the change in slope is arbitrary, but the two-stage relation is meant to approximate conceptual differences in water availability from monsoonal summer storms and winter snowpack. At low altitudes, where precipitation rates are less than $1 \mathrm{ft} / \mathrm{yr}$, summer storms are the primary mechanism for generating recharge. The storms occur infrequently and much of the water is lost to ET, resulting in a low ratio of precipitation converted to recharge. An estimated 30 percent (1,800 acre-ft/yr) of the total recharge in the PMOV groundwater basin occurs in areas with precipitation rates of less than $1 \mathrm{ft} / \mathrm{yr}$ (fig. $7 B$ ). 


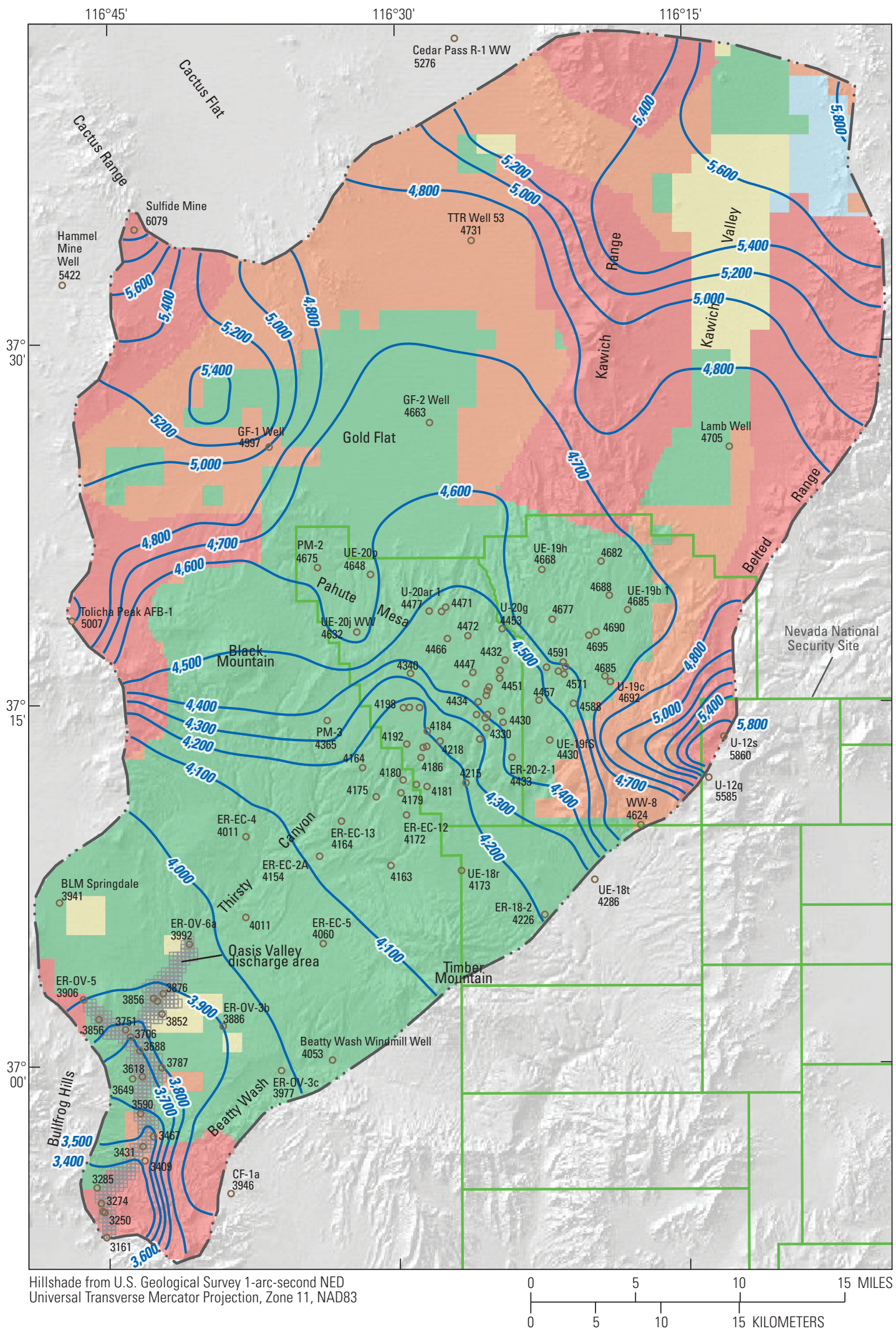

EXPLANATION

Modeled hydrogeologic unit-Modified from Belcher and Sweetkind (2010)

Young volcanic and sedimentary-rock basin fill

Old volcanic and sedimentary-rock basin fill

Volcanic rock, undifferentiated

Carbonate rock

Low-permeability siliciclastic rocks

$-4,200-$ Simulated water-level contour, in feet above NGVD29-Contour interval variable

4624。 Water-level measurementNumber is measured water-level altitude, in feet above NGVD29

$\square \quad$ Discharge point and water-level observation in groundwater evapotranspiration area

Figure 5. Extent of the steady-state PMOV flow model, hydrogeologic-unit distribution, measured water levels from selected wells, and groundwater-discharge area, Pahute Mesa-Oasis Valley groundwater basin, Nevada. 


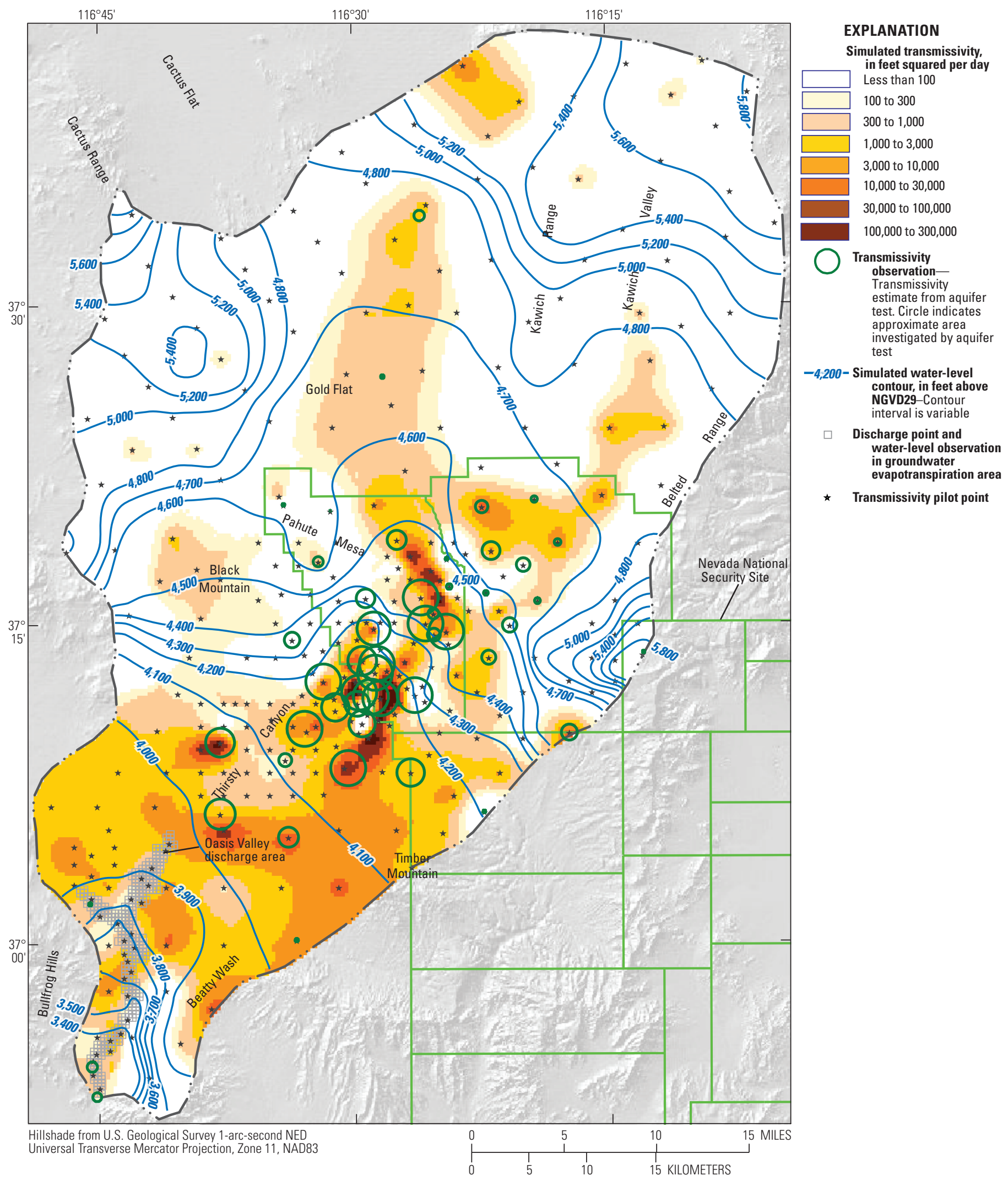

Figure 6. PMOV flow model simulated transmissivity distribution, transmissivity observations from aquifer tests, simulated water levels, discharge area, and transmissivity pilot points, Pahute Mesa-0asis Valley groundwater basin, Nevada. 

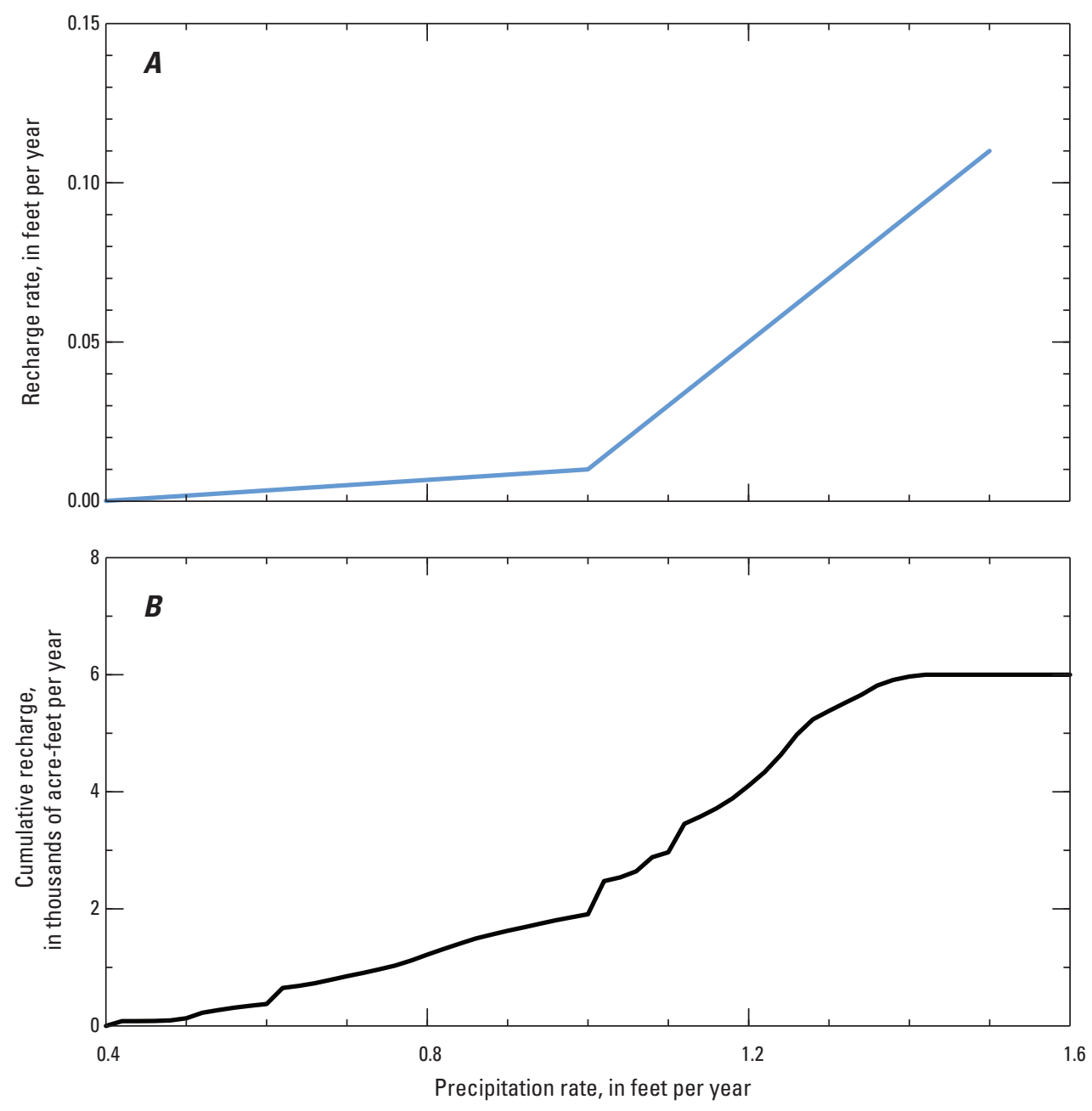

Figure 7. Relation between precipitation rate and $(A)$ conceptual recharge rate from infiltration and runoff to the PMOV flow model and $(B)$ cumulative recharge resulting from this relation, Pahute Mesa-Oasis Valley groundwater basin, Nevada.

At higher altitudes, where precipitation rates are greater than $1 \mathrm{ft} / \mathrm{yr}$, winter snowpack generates most of the recharge and a higher ratio of the precipitation is converted to recharge. In the absence of low-permeability bedrock, all available water is assumed to infiltrate below the root zone and migrate to the water table.

In areas of low-permeability bedrock, a small (less than $0.01 \mathrm{ft} / \mathrm{yr}$ ) volume of water is conceptualized to infiltrate directly into the low-permeability bedrock, but most available water is assumed to run off and infiltrate downgradient on alluvial fans (fig. 8). Recharge from runoff was estimated in Gold Flat and Kawich Valley, where water levels indicated that some local recharge from runoff was occurring. The volume of water available for recharge on fans was halved because runoff is subject to greater evaporative losses in alluvial channels. Recharge is assumed not to occur on valley floors, which were defined as areas with land-surface slopes of less than 1.5 percent. The valley floors have clay-rich soils, low precipitation rates, and warm air temperatures, which promote retention of soil water and evapotranspiration. The relation between total conceptual recharge and precipitation in excess of $1 \mathrm{ft} / \mathrm{yr}$ was adjusted so that the cumulative volume of annual recharge totaled 5,900 acre-ft, equal to the groundwater discharge from Oasis Valley (table 1; Reiner and others, 2002).

Recharge was distributed throughout the PMOV flow model with a total of 355 pilot points (fig. 9). Recharge rates were interpolated from pilot points to model cells with kriging (Doherty, 2010b). Spatial variability of recharge was defined with an isotropic, exponential variogram, where nugget and range were 0 and 100,000 ft, respectively. Interpolation did not differentiate between hydrogeologic units because volcanic rocks dominate more than 90 percent of the recharge areas. Recharge rates to low-permeability rocks (fig. 8) were constrained by limiting transmissivities to less than $1 \mathrm{ft}^{2} / \mathrm{d}$ in these rocks. 


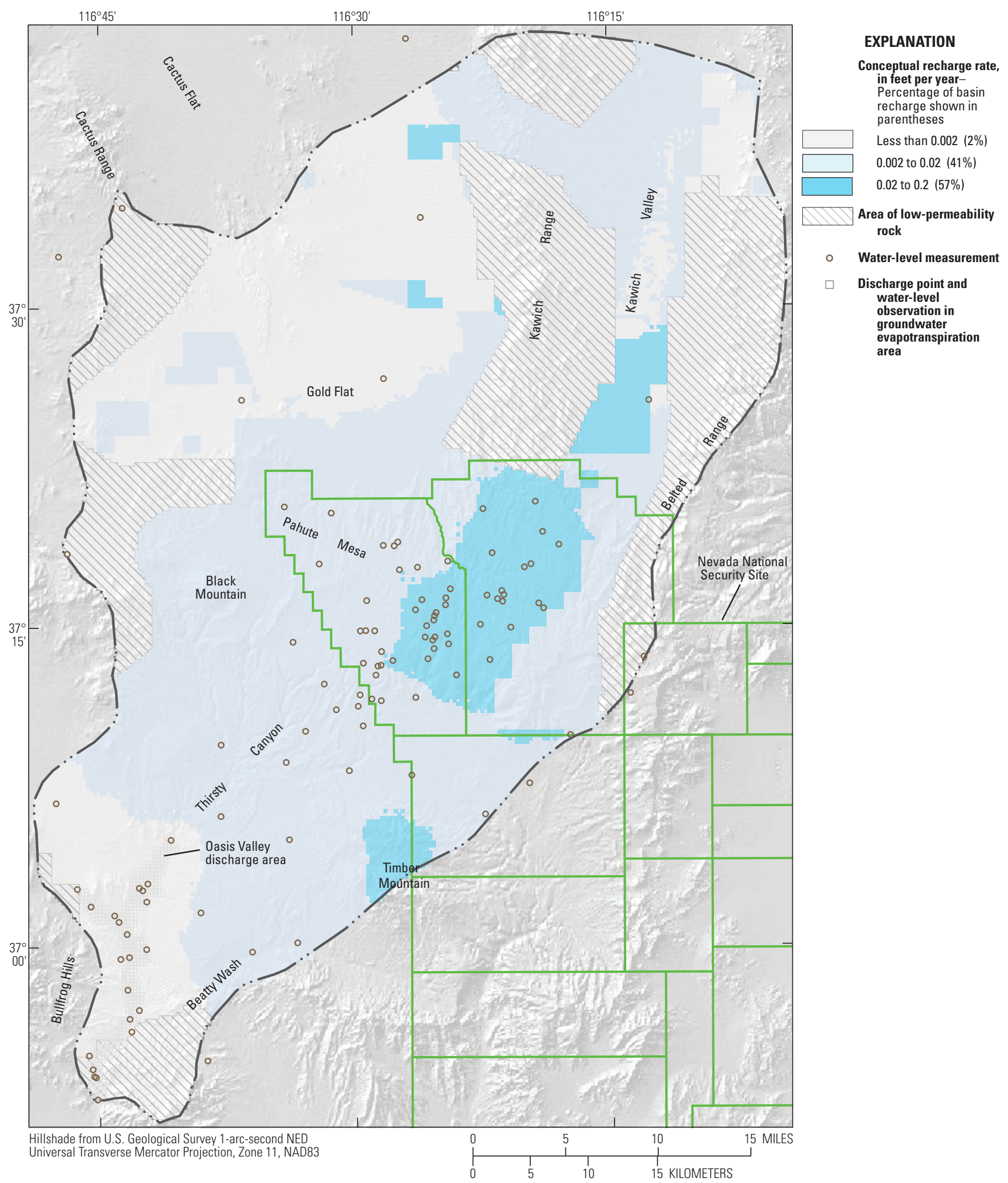

Figure 8. PMOV flow model conceptual recharge rates used as initial condition for model, areas of low-permeability rock, waterlevel measurement locations, and discharge area, Pahute Mesa-Oasis Valley groundwater basin, Nevada. 




EXPLANATION

Recharge rate, in feet per year-Percentage of basin recharge shown in parentheses

Less than $0.002(3 \%)$

0.002 to $0.02(49 \%)$

0.02 to $0.2(48 \%)$

$-4,200-$ Simulated water-level contour, in feet above NGVD29- Contour interval is variable

Chloride concentration, in milligrams per liter-Data from Rose and others (2006)

$0^{6.5} \quad 0$ to 25

$\bigcirc^{50} \quad 26$ to 50

$0^{59}$ Greater than 50

$\square \quad$ Discharge point and water-level observatio in groundwate evapotranspiration area

$\star$ Recharge pilot point

Figure 9. PMOV flow model simulated recharge rates from calibrated model, simulated water levels, chloride concentrations, discharge area, and recharge pilot points, Pahute Mesa-Oasis Valley groundwater basin, Nevada. 
Transmissivity and recharge distributions were estimated by minimizing a weighted composite, sum-of-squares objective function. These distributions were defined with 650 pilot points, where 90 percent of the points were adjusted with PEST (Doherty, 2010a). Differences between measured and simulated observations defined the goodness-of-fit or improvement of calibration.

Unrealistic hydraulic-property distributions were avoided by preventing over-fitting of the observations (Fienen and others, 2009). Goodness-of-fit was limited so that the weighted, sum-of-squares error could not be reduced to less than irreducible measurement and numerical model errors. This expected measurement error is a weighted, sum-of-squares error and is the variable PHIMLIM in a PEST control file (Doherty, 2010a). A PHIMLIM of 30,000 $\mathrm{ft}^{2}$ was specified, which is equivalent to a RMS error of about $15 \mathrm{ft}$ for water-level measurements and approximates the average allowable misfit between simulated and measured water level at each well.

Measurement and regularization observations controlled model calibration. Measured water levels, GWET water levels, land-surface altitude, and transmissivity estimates from aquifer-test results were measurement observations. Estimated values of transmissivity and recharge are guided by regularization observations to preferred conditions where parameters are insensitive to measurement observations. This approach is known as Tikhonov regularization (Doherty, 2010a).

Tikhonov regularization limited differences between pilot points by penalizing sharp differences, and thereby ensuring relatively continuous transmissivity and recharge distributions (Doherty and Johnston, 2003). Contrasts across hydrogeologic changes were not penalized. Tikhonov regularization observations were specified with equations that defined expected ratios of log-transmissivities or log-recharge rates between pilot points. Ratios of 1 were specified between pilot points that distributed transmissivities to impose preferred homogeneity. Ratios between pilot points that distributed recharge rates represented differences in conceptual recharge rates. Transmissivity and recharge estimates departed from regularization observations where dictated by measured water levels and field estimates of transmissivity.

\section{Measurement Observations}

Measured and simulated water levels were compared from 102 wells in the PMOV groundwater basin (figs. 5 and 10). Eighty-five of the wells are screened in volcanic rock and 16 wells are completed in basin fill. Simulated water levels were linearly interpolated laterally to points of measurement from the centers of surrounding cells with MOD2OBS (Doherty, 2010b).

Water levels were estimated at 335 groundwaterdischarge locations and compared to simulated water levels in Oasis Valley. Water levels are within 10-20 ft of land surface in groundwater-discharge areas. Water levels exceed land surface at spring pools and remain below land surface in evapotranspiration areas. Water levels can be estimated with land surface altitudes from a DEM that sampled 1:24,000-scale maps every $30 \mathrm{~m}$ and reported to the nearest whole meter (Gesch and others, 2009). DEM altitudes in model cells where groundwater discharge by ET occurred typically spanned $10 \mathrm{ft}$. Water levels were assumed equal to average land-surface altitudes because variability of land surface exceeds measured differences between land surface and water levels. These observations are referred to as GWET water levels (fig. 10), which are less certain than measured water levels from wells and were weighted less.

Simulated water levels were compared to land-surface altitudes to ensure that simulated water levels remained below land surface. Land-surface altitude observations were sampled at 1,208 locations using the DEM used for the GWET water levels. Simulated water levels that were below land surface were replaced with the land-surface altitude so the residual equaled zero and did not affect model calibration. For example, a simulated water level of 4,500 ft would be changed to $5,000 \mathrm{ft}$, where land-surface altitude is $5,000 \mathrm{ft}$, and the residual would be $0 \mathrm{ft}$. Alternatively, a simulated water level of 5,500 $\mathrm{ft}$ at the same location would not be changed and the residual would be $500 \mathrm{ft}$.

Transmissivity estimates from aquifer-test results were compared to simulated transmissivities that were averaged from multiple model cells. Cells were averaged if they occurred within the area investigated by an aquifer test (fig. 6). The area investigated was defined where drawdowns exceeded $0.1 \mathrm{ft}$ at the end of each aquifer test, but the radius of investigation was not allowed to exceed 5,000 ft. Simulated transmissivities from model cells in the sampled area were averaged arithmetically.

Annual discharge from Oasis Valley mostly could not change because 5,900 acre-ft was specified as distributed GWET. This limited discharge observations to subsurface flow from Oasis Valley to Amargosa Desert that was simulated with a single, specified head. This subsurface discharge was estimated previously as $100 \mathrm{acre}-\mathrm{ft} / \mathrm{yr}$ and occurs through a narrow section of saturated alluvium (Reiner and others, 2002). Previously estimated and simulated discharges agreed within 1 acre-ft/yr.

Weights were assigned to observations to represent expected observation accuracy and importance of each observation to model fit. Weights were adjusted iteratively so all observation types affected model calibration. Measured water levels, GWET water levels, and land-surface altitude observations were assigned weights of $1,0.1$, and 0.1 , respectively. Transmissivity estimates from aquifer-test results were weighted differently (see section, "Regularization Observations") because hydrogeologic units differed and variable volumes of rock were investigated by aquifer tests. Absolute values of weights did not affect calibration results because model fit was evaluated exclusively with unweighted residuals. 


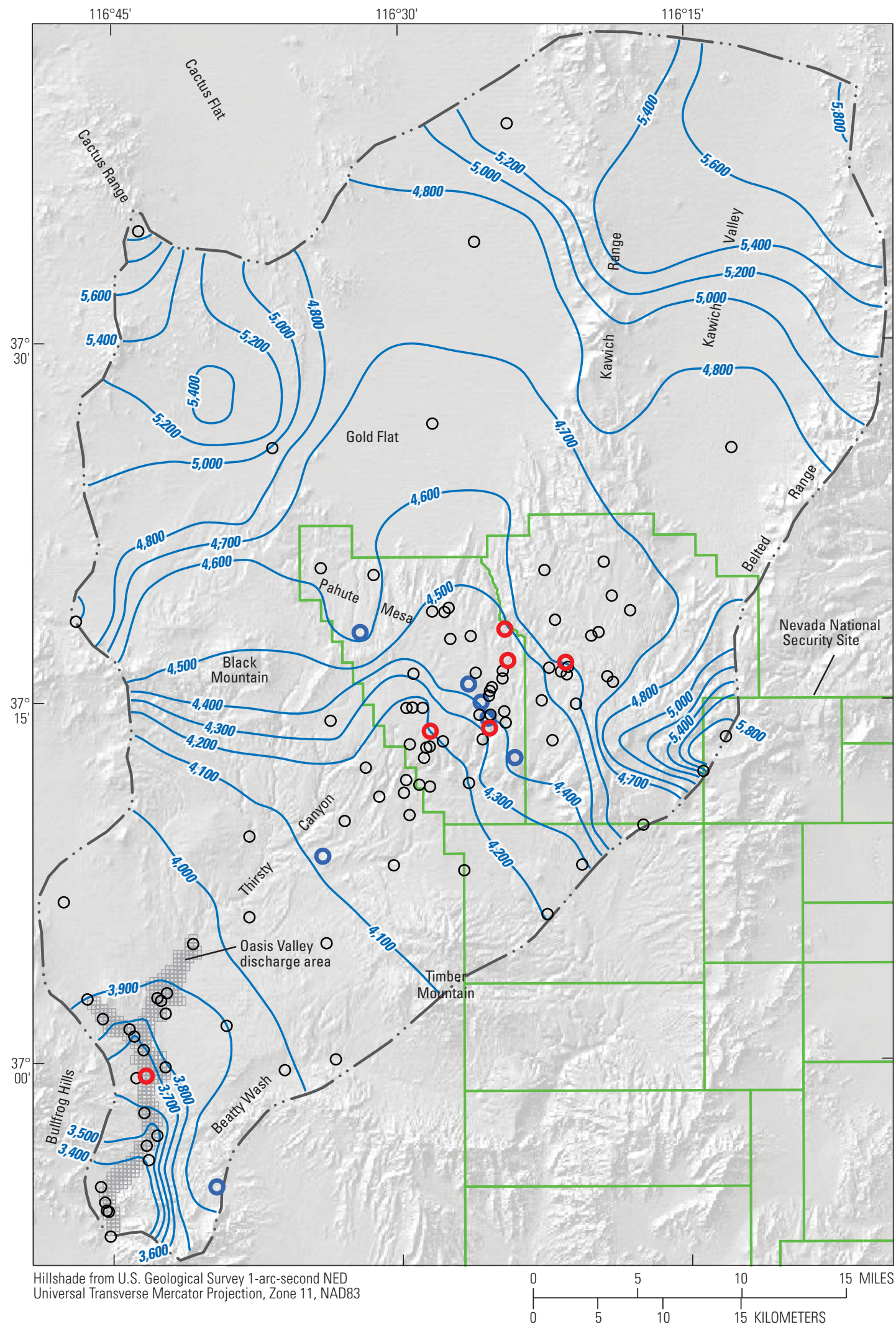

EXPLANATION

$-4,200-$ Simulated water-level contour, in feet above NGVD29-Contour interval is variable

Measured water-level residual-Simulated minus measured water level, in feet

- 20 to 25

O $\quad-20$ to 20

- -37 to -20

Discharge point and water-level observation in groundwater evapotranspiration area

Figure 10. PMOV flow model simulated water levels, water-level residuals, and discharge area, Pahute Mesa-0asis Valley groundwater basin, Nevada. 


\section{Regularization Observations}

Regularization observations are equations that quantify preferred relations between pilot points defining recharge or transmissivity distributions. Regularization observations affected calibration most where the PMOV flow model was insensitive to measurement observations.

Regularization observations were weighted inversely to data density so that preferred relations were emphasized where measurement observations were few. Regularization observations were weighted relative to minimum distances between the two nearest measured water levels. Regularization observations were weighted equally where separation between the nearest pilot point and measured water level was less than the distance between the two nearest measured water levels. Weights decreased inversely with distance where pilot points were farther from the nearest measured water level than the distance between the two nearest measured water levels. Distances between measured water levels average $1 \mathrm{mi}$ in the northwestern part of the NNSS and exceed 8 mi north of the NNSS.

Ratios of the conceptual average annual recharge (fig. 8) were the preferred relation between pilot points for the recharge distribution. These initial recharge estimates were sampled from the conceptual recharge distribution at pilot points (fig. 9). Recharge rates were estimated independently at all pilot points, but preferred ratios of conceptual recharge rates did not change between pilot points during calibration. For example, rates of 0.038 and $0.002 \mathrm{ft} / \mathrm{yr}$ were sampled from the conceptual recharge distribution at the northernmost pilot points in the NNSS and Gold Flat, respectively. Calibration increased rates 12 percent at these two pilot points, whereas the regularization observation maintained a ratio of recharge being 19 times greater at the pilot point on the NNSS than at the pilot point in Gold Flat. About 25,000 regularization observations constrain recharge estimates with these preferred relations.

Homogeneity within simplified hydrogeologic units (fig. 5) was the preferred relation between pilot points for the transmissivity distribution. Hydrogeologic units were incorporated as observations instead of as parameters, so transmissivity in a hydrogeologic unit could differ where dictated by measurement observations. Weights for these regularization observations were reduced tenfold if either transmissivity pilot point intersected an area that was sampled by a transmissivity observation (fig. 6). This minimized conflict between assumed homogeneity within simplified hydrogeologic classes and observed transmissivity estimates.
More than 21,000 regularization observations constrained transmissivity estimates with these preferred relations.

\section{Goodness of Fit}

Simulated water levels compare favorably to measured water levels in the PMOV flow model (fig. 10). Water-level residuals show little spatial pattern of significance, suggesting a good overall fit between simulated and measured water levels. Average and RMS water-level errors of -1.6 and $12 \mathrm{ft}$, respectively, are not large relative to the 2,700-ft range of measured water levels (fig. 11). Measured water-level altitudes range from 3,161 to 5,860 ft in southern Oasis Valley and the east-central part of the flow model area, respectively. Minimum and maximum water-level residuals range from -37 to $25 \mathrm{ft}$ (fig. 10), and 88 percent of simulated water levels are within $20 \mathrm{ft}$ of measured water levels.

Measured and GWET water-level residuals with absolute values of greater than $50 \mathrm{ft}$ are considered significant. Measured water-level residuals, all of which were less than $50 \mathrm{ft}$, are small relative to the more than $800-\mathrm{ft}$ range of water levels in areas where groundwater discharges to Oasis Valley (fig. 5). Simulated GWET water-level residuals have a RMS error of $39 \mathrm{ft}$, and 86 percent of the residuals are within $50 \mathrm{ft}$ of measured targets.

A consistent bias exists in the GWET water-level residuals because remote sensing was used to distribute groundwater discharge (Reiner and others, 2002). Groundwater discharge was simulated where vegetation was mapped, which occurs around and downgradient of spring outlets, rather than where the water first discharges from the ground. Vegetation was used as a surrogate for discharge location because direct measurement of springs and seeps accounts for only about one-half of the discharge in Oasis Valley (Reiner and others, 2002). As a simple approach, GWET water levels were assigned land-surface altitude, whereas water levels in the vegetated areas likely are 10-20 ft below land surface. The bias in the residuals is indicated between measured altitudes of 3,200 and 4,000 ft, where simulated GWET water-levels average about $22 \mathrm{ft}$ less than measured values (fig. 11).

Simulated and measured transmissivities compare well, and all but one comparison are within a factor of 10 (fig. 12). Simulated and measured transmissivities geometrically average 600 and $520 \mathrm{ft}^{2} / \mathrm{d}$, respectively. The log standard deviation of residuals from transmissivity observations is 0.28 or a multiplier of 1.9 , which is similar to the error associated with aquifer-test results. 


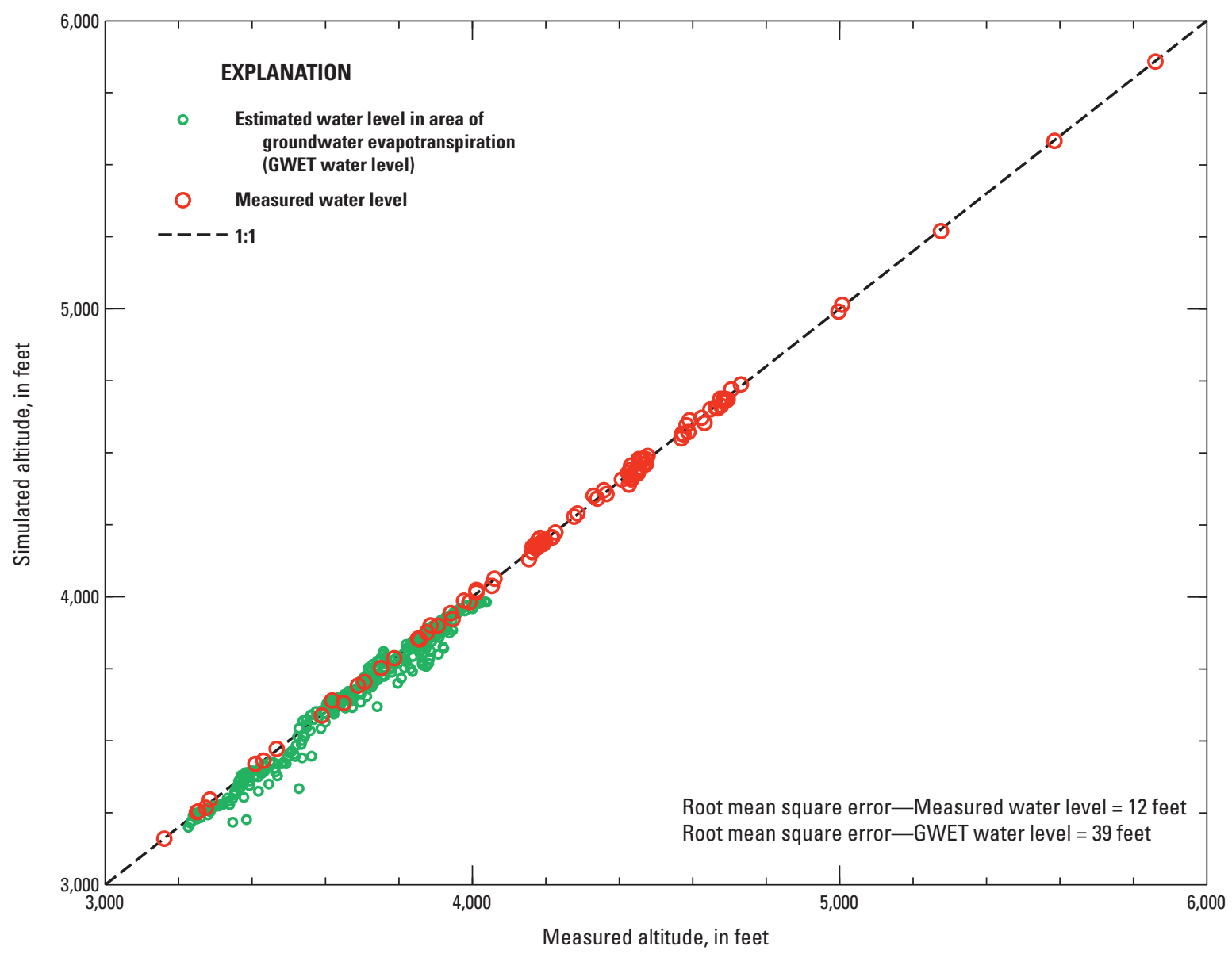

Figure 11. Comparison of simulated water levels for the calibrated PMOV flow model to estimated water levels in areas of groundwater evapotranspiration (GWET water levels) and measured water levels, Pahute Mesa-Oasis Valley groundwater basin, Nevada.

\section{Model Simulation Results}

The PMOV flow model shows that hydrologic data in the PMOV groundwater basin are internally consistent with the delineated no-flow basin boundary. The regional analysis shows that sufficient recharge can be generated within the basin boundary to supply the discharge to Oasis Valley. Most of this recharge originates on Pahute Mesa, with the highest rates centered on the eastern part of the mesa (fig. 9).

Groundwater chloride concentrations are consistent with the recharge as distributed in the PMOV flow model (fig. 9). The lowest concentrations occur on eastern Pahute Mesa and to the south near Timber Mountain. These areas have relatively high rates of recharge, resulting in less evapo-concentration of initial chloride concentrations in precipitation (Cooper and others, 2013). Conversely, to the west, chloride concentrations are 10-30 times higher and simulated recharge rates are about
10 times lower. Downgradient of the NNSS and into Oasis Valley, chloride concentrations are intermediate, suggesting mixing of the two groundwater types (Rose and others, 2006).

Simulated flow through the PMOV groundwater basin (fig. 13) is similar to the regional flow patterns depicted on plate 1. Water generally flows from north to south-southwest, discharging at Oasis Valley. North of the NNSS, small amounts of recharge on low-permeability rocks (fig. 8) have elevated water levels in upland areas and most water is focused into Gold Flat and Kawich Valley. Water levels north of the NNSS are simulated with high east-west gradients away from the mountains and lower southward gradients through adjacent valleys. Low gradients are indicated by three water levels in Gold Flat and Kawich Valley north of the NNSS, ranging from 4,731 to 4,663 ft (GF-2 Well, TTR Well 53, and Lamb Well; fig. 5), which are only about 10-60 ft higher than water levels on the northern end of the NNSS. 


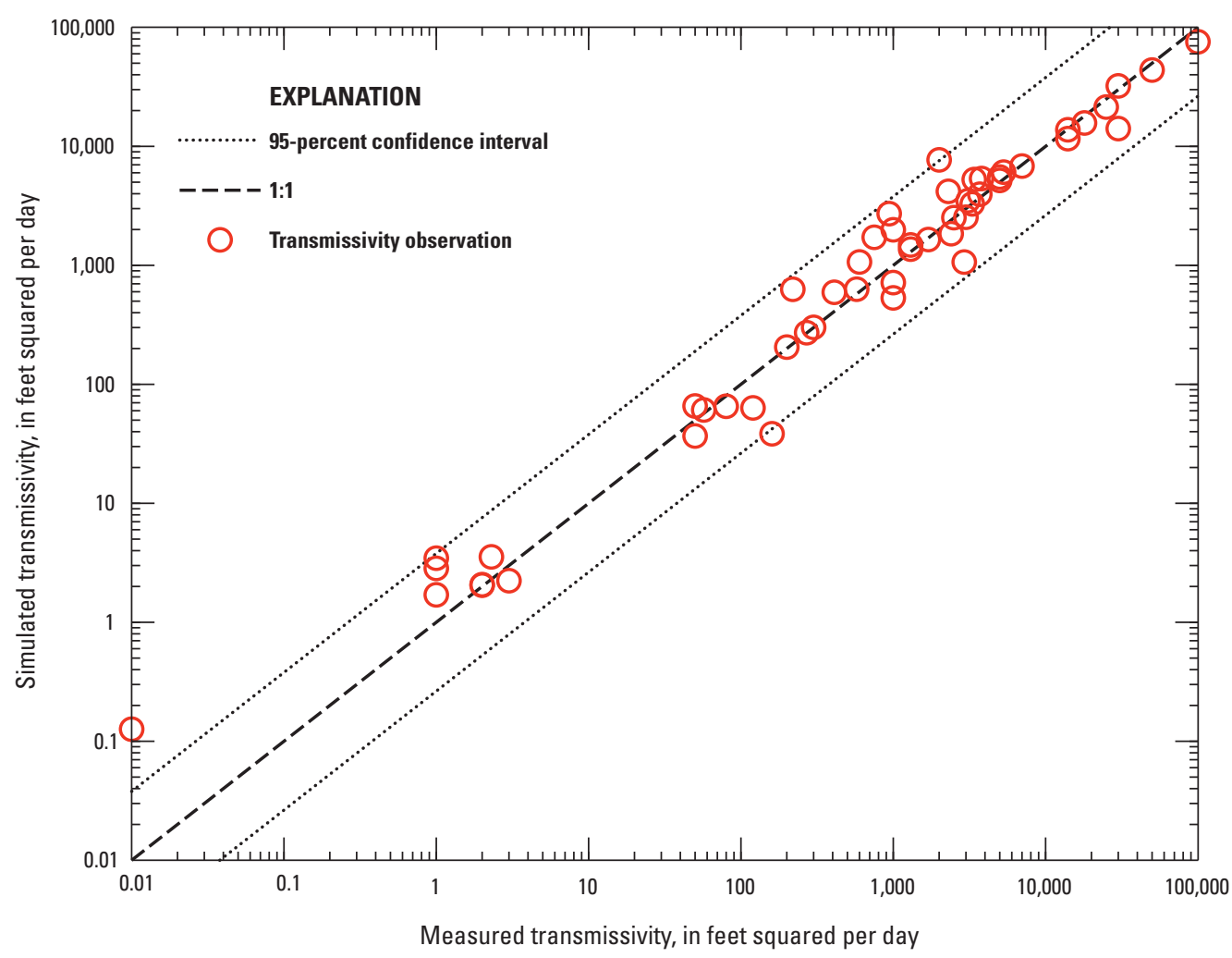

Figure 12. Comparison of simulated and measured transmissivities for the PMOV flow model, Pahute Mesa-Oasis Valley groundwater basin, Nevada.

Flow is southwesterly from the NNSS to Oasis Valley and is well-constrained by data. Relatively low hydraulic gradients occur in the area of Thirsty Canyon, between the NNSS and Oasis Valley. Transmissivities are especially high just southwest of the NNSS, where they locally exceed $100,000 \mathrm{ft}^{2} / \mathrm{d}$ as a result of thick rhyolite lava flows (NavarroIntera, LLC, 2011; Jackson and others, 2014). A band of transmissive rocks is simulated from the northwestern edge of the NNSS to the northern end of Oasis Valley (fig. 6). These rocks promote flow to Oasis Valley and, in conjunction with low recharge (fig. 9), generate a low hydraulic gradient in this area.

Simulated average linear groundwater velocities for a porosity-thickness product ${ }^{1}$ of $50 \mathrm{ft}$ in the PMOV groundwater basin are shown in figure 13, where magnitude is indicated by colored fill and flow direction is perpendicular to the simulated head contours. The velocity field is controlled by the distribution of recharge and transmissivity. Groundwater velocities generally are low north of the NNSS, where recharge, upgradient flows, and transmissivity are low.

\footnotetext{
${ }^{1}$ A porosity-thickness product is a lumped term that accounts for the average effective porosity and thickness of rock contributing to groundwater flow without having to know either factor independently. For example, a porosity of 5 percent and a thickness of $1,000 \mathrm{ft}$ or a porosity of 10 percent and a thickness of $500 \mathrm{ft}$ both have a porosity-thickness product of $50 \mathrm{ft}$.
}

Groundwater in this area is conceptualized as old and slow moving. Contrarily, velocities are 10 to more than 100 times higher from Pahute Mesa to Oasis Valley. Locally, velocities exceed $1 \mathrm{ft} / \mathrm{d}$. This is not inconsistent with radionuclide transport observed from the Benham nuclear test. Tritium from this test was measured in a well 4,400 ft downgradient 27 years after the test (U.S. Department of Energy, 1997b; Wolfsberg and others, 2002), resulting in a documented transport rate of at least $160 \mathrm{ft} / \mathrm{yr}$. Simulated flow velocities (fig. 13) reasonably can exceed tritium transport rates from field measurements because dispersion, retardation, and radioactive decay are not simulated.

The highest flow velocities occur between the area of underground nuclear testing and Oasis Valley (fig. 13). Simulated flow paths from all nuclear test locations on Pahute Mesa are to the Oasis Valley discharge area. The precise location where the simulated flow path for each test discharges in Oasis Valley, as shown in figure 13, is not meaningful. This is because the simulated discharge in Oasis Valley was apportioned based on the distribution of evapotranspiration rather than where the groundwater initially discharges in Oasis Valley. For example, groundwater may discharge to the surface from the volcanic rocks at specific locations based on geologic and structural relations, but then reinfiltrates the surrounding alluvium. This focused discharge may saturate the entire alluvial valley, allowing plant roots to reach the water and remove it from the ground in areas distant from the initial points of discharge. 


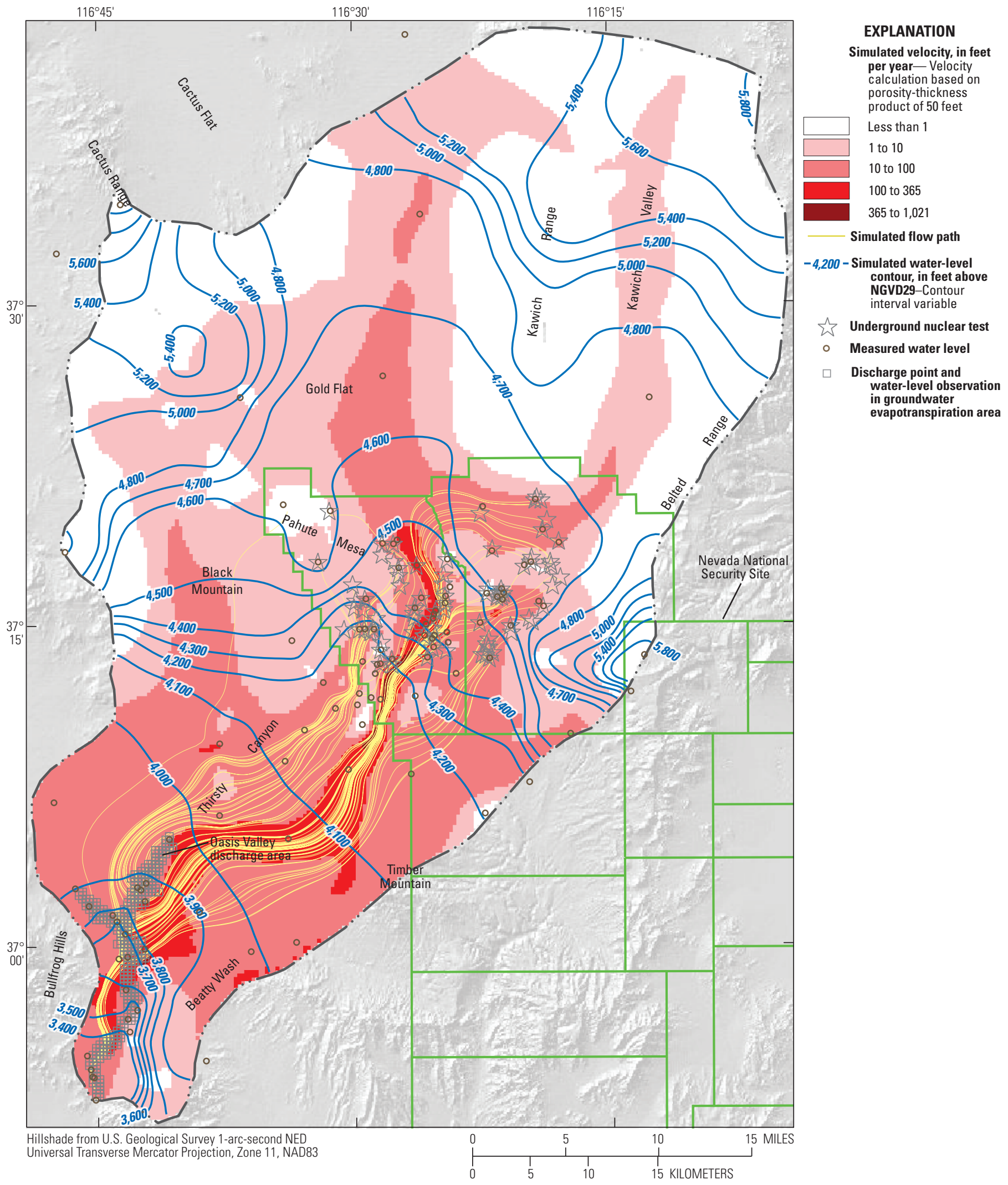

Figure 13. Groundwater velocity field, simulated groundwater flow paths, simulated water levels, and underground nuclear tests in the PMOV flow model, Pahute Mesa-Oasis Valley groundwater basin, Nevada. Magnitude of velocity is indicated by colored fill and flow direction is perpendicular to simulated water-level contours. 


\section{Boundary Uncertainty}

Uncertainty in the location of the PMOV groundwater basin boundary is indicated with seven alternative boundaries (fig. 14) that were developed as part of the regional and local analyses. Most of the boundary uncertainty occurs on the western and northern parts of the basin boundary. These areas have limited data to constrain the boundary.

Multiple boundaries extending to the northern end of Gold Flat were delineated and analyzed. All but the last boundary were discarded for various reasons, such as discrepancies with reinterpreted water-level contours or imbalances with basin discharges. One alternative boundary was drawn north of Gold Flat to incorporate Cactus Flat. This boundary was determined to be implausible based on model simulation results and a chloride mass-balance analysis. The final boundary, determined to be the most plausible, is presented in the section, "Final Pahute Mesa-Oasis Valley Basin Boundary." The uncertainty along different sections of the boundary is discussed.

\section{Alternative Boundaries Extending to Northern Gold Flat}

All but one of the alternative boundaries extend only as far as northern Gold Flat. The boundaries for these alternatives are mostly consistent on their southeastern and northern sides but vary significantly on their western sides.

As part of the iterative process of boundary delineation, (1) water-level contours in the western and northern parts of the PMOV groundwater basin from U.S. Department of Energy (1997a) were re-interpreted based on newer water-level data stored in the U.S. Geological Survey National Water Information System (U.S. Geological Survey, 2015b), and (2) Sarcobatus Flat discharge estimates were revised downward from 13,000 to 7,500 acre-ft/yr (appendix A). These changes allowed the western sides of alternative boundaries to be shifted farther westward. The final delineation of the PMOV groundwater basin (fig. 14) is consistent with the water-level contours and provides sufficient water to the Sarcobatus Flat groundwater basin.

Some alternative boundaries of the PMOV groundwater basin (fig. 14) included discharge from the Bullfrog Hills west of Oasis Valley, consistent with the area of discharge reported in Reiner and others (2002). The Bullfrog Hills groundwater basin (pl. 1) is not considered part of the PMOV groundwater basin and is believed to be hydraulically separated from the discharge in Oasis Valley. Bullfrog Hills, consisting of lowpermeability rocks, contains small springs that are attributed to localized flow paths from recharge in the nearby highlands (Reiner and others, 2002; White, 1979). The small amounts of discharge seeping from low-permeability rocks in Bullfrog Hills to Oasis Valley is considered negligible.

\section{Alternative Boundary Incorporating Cactus Flat}

An alternative boundary incorporating Cactus Flat was tested to determine if Cactus Flat was part of the PMOV groundwater basin, because the groundwater divide between Ralston Valley and Gold Flat is poorly constrained. The poor constraint is a result of a low hydraulic gradient in central Cactus Flat, so that existing water levels alone cannot be used to determine whether water flows southward into the PMOV groundwater basin or northwestward toward discharge areas in Ralston or Clayton Valleys (pl. 1). An alternative PMOV boundary incorporating Cactus Flat to the north (fig. 14) was tested with the regional basin-balance model and a local-scale numerical model to determine if water in central Cactus Flat can flow to Oasis Valley. The Kawich and Cactus Ranges, which bound Cactus Flat, consist of low-permeability siliciclastic rocks that function as flow barriers (fig. 15). Recharge waters from these ranges are directed southwest and northeast into Cactus Flat. Testing of the alternative PMOV boundary required that simulated flow move south from Cactus Flat to Gold Flat.

The Cactus Flat alternative boundary is not a plausible boundary for the PMOV groundwater basin. The Kawich Range, and the Cactus Range to a much lesser extent, are significant sources of groundwater recharge to Cactus Flat (pl. 1). About 1,900 acre-ft/yr of recharge is estimated for these ranges, based on the regional analysis (appendix B). The best-fit regional analysis using the Cactus Flat alternative boundary has about 1,500 acre-ft/yr more recharge than discharge (7,800 as compared to 6,300 acre-ft/yr) in the PMOV groundwater basin. Although, not definitive, this imbalance suggests that the contributing area for the Cactus Flat alternative boundary is too large.

The Cactus Flat alternative boundary also was tested with a single-layer numerical model using the methods and data described in the section, "Local-Scale Analysis." The model has no-flow lateral boundaries and no discharge locations within Cactus Flat, which forces recharge to flow to the discharge area in Oasis Valley. Fourteen additional head observations were included in Cactus Flat for the alternative model (fig. 15). Recharge in Cactus Flat was simulated as runoff recharge that was distributed on the alluvial fans adjacent to the Kawich and Cactus Ranges. The Cactus Flat alternative boundary model was calibrated with RMS errors of 23 and $42 \mathrm{ft}$ for water-level and GWET waterlevel observations, respectively. The log standard deviation of residuals from transmissivity observations was 0.29 or a multiplier of 1.9 .

The alternative boundary for Cactus Flat was rejected because the calibrated, local-scale model required physically unrealistic transmissivities in Gold Flat to match water-level measurements in Cactus Flat. The calibrated, local-scale model could not simulate large movements of water south from Cactus Flat. Flow from Cactus Flat into Gold Flat is 


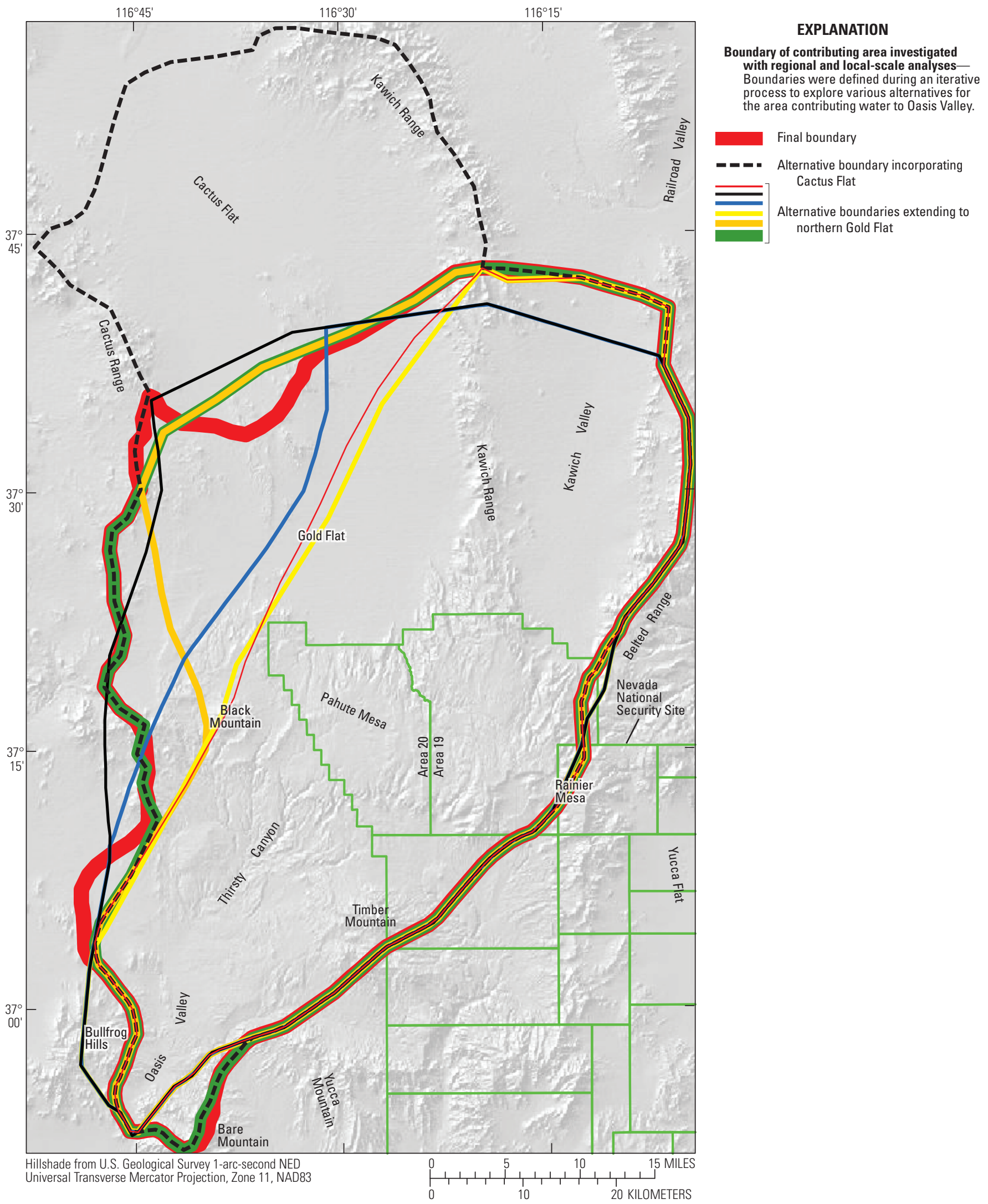

Figure 14. Boundaries investigated with regional and local-scale analyses to determine the contributing area for the Pahute Mesa-Oasis Valley groundwater basin, Nevada. 


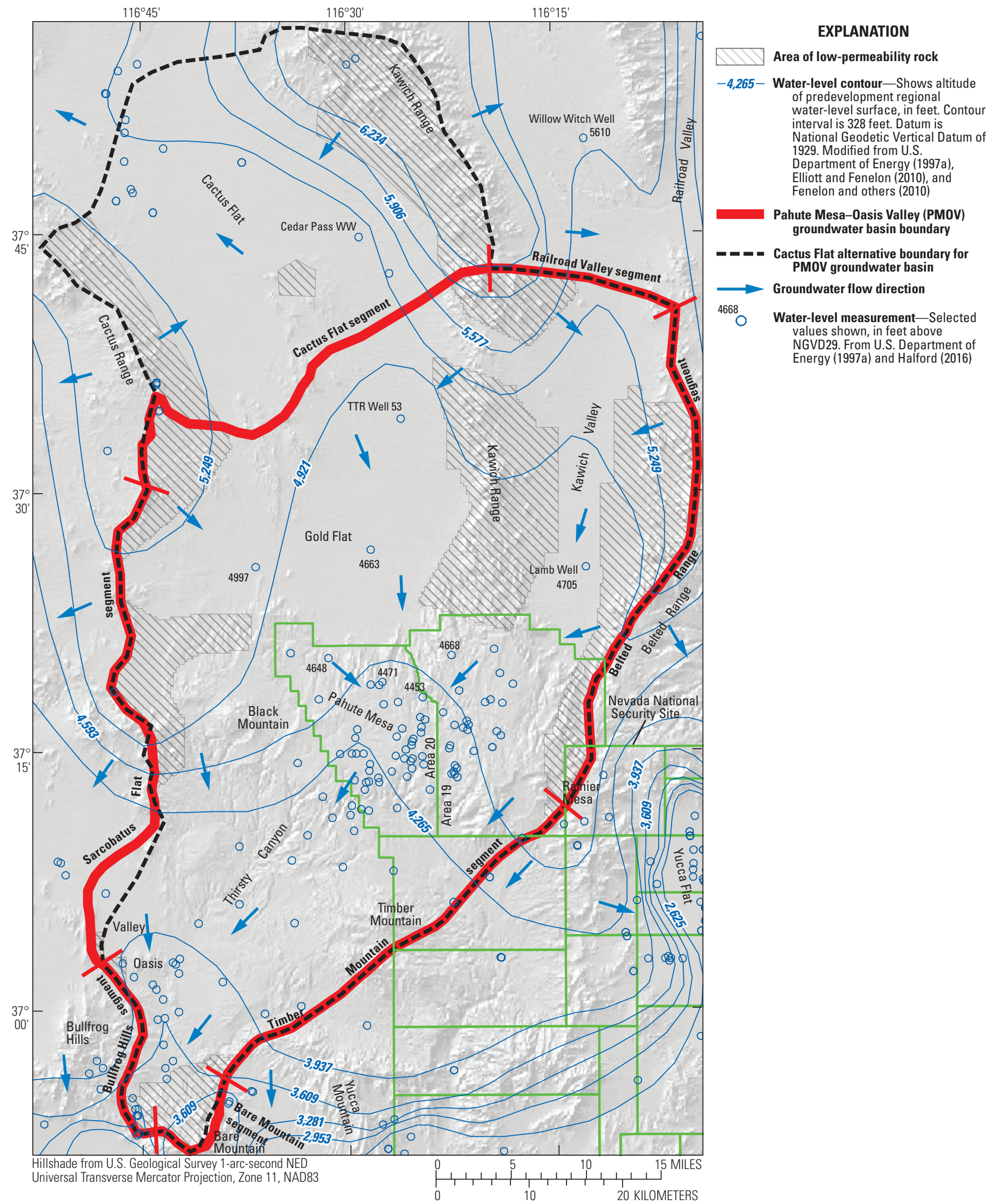

Figure 15. Areas of low-permeability rock and groundwater flow directions in the Pahute Mesa-0asis Valley groundwater basin and the Cactus Flat area, Nevada. Selected water levels show groundwater trough where water is funneled into the center of Pahute Mesa. 
restricted because transmissivities in Gold Flat are moderate to low and the hydraulic gradient is low. Additionally, flow from Gold Flat into the northern end of the NNSS converges on a narrow, transmissive corridor centered near the boundary between NNSS Areas 19 and 20. The corridor is evidenced by water levels that are lowest near the center of Gold Flat and near the boundary between Areas 19 and 20 (fig. 15). The narrow flow corridor restricts the amount of flow that can enter the NNSS from the north. During calibration of the alternative model, recharge in Cactus Flat was reduced from a preferred $1,900 \mathrm{acre}-\mathrm{ft} / \mathrm{yr}$ to less than $200 \mathrm{acre}-\mathrm{ft} / \mathrm{yr}$ (table 2). Similar to results from the regional analysis, this indicates that recharge in Cactus Flat does not flow south into Gold Flat and that Cactus Flat is not part of the PMOV groundwater basin.

Chloride mass balance also invalidates the Cactus Flat alternative boundary and supports the final PMOV boundary within the limits of the assumptions (table 2). Chloride concentrations in precipitation range from 0.42 to $0.47 \mathrm{mg} / \mathrm{L}$, based on studies of the regional area (Dettinger, 1989) and Pahute Mesa (Cooper and others, 2013), respectively. Annual precipitation to the Cactus Flat alternative and final PMOV boundary areas totaled 895,000 and 690,000 acre-ft, respectively. Annual recharge was 6,000 acre-ft for both boundary areas because recharge was constrained by groundwater discharge from Oasis Valley and minor subsurface flow to the AFFCR groundwater basin (table 2). An average groundwater chloride concentration for the PMOV groundwater basin can be calculated as:

$$
\mathrm{Cl}_{g w}=\mathrm{Cl}_{p p t} P / R
$$

where

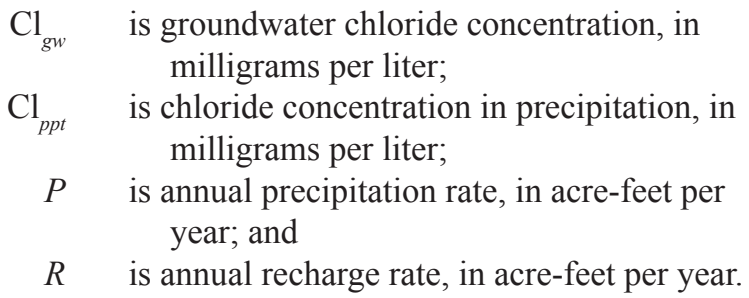

Using equation 2 and applying the range of chloride concentrations in precipitation to the final PMOV boundary area, an integrated groundwater chloride concentration near the Oasis Valley discharge area is expected to range between 48 and $54 \mathrm{mg} / \mathrm{L}$ (table 2). In comparison, the calculated groundwater chloride concentration for the Cactus Flat alternative boundary area ranges between 63 and $70 \mathrm{mg} / \mathrm{L}$.

\begin{tabular}{|c|c|c|}
\hline $\begin{array}{l}\text { Annual volume } \\
\text { (acre-ft/yr) }\end{array}$ & $\begin{array}{l}\text { Final } \\
\text { PMOV }\end{array}$ & $\begin{array}{l}\text { Cactus Flat } \\
\text { alternative }\end{array}$ \\
\hline Precipitation & 690,000 & 895,000 \\
\hline Recharge to final PMOV area & 6,000 & 5,800 \\
\hline Recharge to Cactus Flat area & - & 200 \\
\hline Total recharge & 6,000 & 6,000 \\
\hline Groundwater ET in Oasis Valley ${ }^{1}$ & 5,900 & 5,900 \\
\hline Subsuface flow to AFFCR basin & 100 & 100 \\
\hline Total discharge & 6,000 & 6,000 \\
\hline $\begin{array}{l}\text { Average chloride concentration } \\
\qquad(\mathrm{mg} / \mathrm{L})\end{array}$ & $\begin{array}{l}\text { Final } \\
\text { PMOV }\end{array}$ & $\begin{array}{l}\text { Cactus Flat } \\
\text { alternative }\end{array}$ \\
\hline Precipitation, measured & $0.42-0.47$ & $0.42-0.47$ \\
\hline Groundwater, calculated $^{2}$ & $48-54$ & $63-70$ \\
\hline Groundwater, measured ${ }^{3}$ & 45 & 45 \\
\hline
\end{tabular}

Table 2. Groundwater flow budgets and measured and calculated chloride concentrations in precipitation and groundwater for the final PMOV and Cactus Flat alternative groundwater basin boundaries, Pahute Mesa-Oasis Valley groundwater basin, Nevada.

[Abbreviations: PMOV, Pahute Mesa-Oasis Valley; AFFCR, Alkali Flat-Furnace Creek Ranch; ET, evapotranspiration; acre-ft/yr, acre-foot per year; mg/L, milligram per liter; -, Cactus Flat area was not simulated]

${ }^{1}$ Does not include discharge to Bullfrog Hills.

${ }^{2}$ Calculated using equation 2 .

${ }^{3}$ Median value from wells measured in PMOV discharge area. 
The median chloride concentration for wells measured in the Oasis Valley discharge area is $45 \mathrm{mg} / \mathrm{L}$ (fig. 9), which agrees better with an average chloride concentration calculated using the final PMOV boundary.

Chloride mass-balance analyses in the PMOV groundwater basin are limited primarily by the assumption that current infiltration below the root zone is similar to recharge at the water table. This limitation is significant because the average thickness of the unsaturated zone exceeds $900 \mathrm{ft}$ in the PMOV groundwater basin and 1,800 ft beneath NNSS Areas 19 and 20. Moisture content in the unsaturated zone beneath Areas 19 and 20 averaged 17 percent from 173 cores in 18 boreholes (Wood, 2007). Total water volumes of $50,000,000$ and 150,000,000 acre-ft intervene between the root zone and water table beneath Areas 19 and 20 and the PMOV groundwater basin, respectively. Residence times through the unsaturated zone can be calculated using estimated unsaturated water volumes and integrated results from the PMOV model. Residence times in the unsaturated zone are briefest beneath Areas 19 and 20 but still average 15,000 years. Average residence times in excess of 10,000 years suggest that recharge at the water table is affected by paleoclimatic conditions that have occurred from the Pleistocene to the recent time. This greatly limits chloride mass balance and other geochemical analyses that assume infiltration below the root zone and recharge at the water table are similar.

\section{Final Pahute Mesa-Oasis Valley Basin Boundary}

The final PMOV groundwater basin is delineated by the red boundary line in figure 15 . The boundary is divided into segments for discussion. The western boundary (Sarcobatus Flat segment) and northern boundary (Cactus Flat and Railroad Valley segments) are the least constrained and most uncertain. However, the precise location of the western and northern PMOV boundaries is less critical than other boundary locations for determining groundwater flow paths within the PMOV groundwater basin. This is because flow is minimized near these boundaries as a result of low transmissivities (fig. 6), limited recharge (fig. 9), and slow groundwater velocities (fig. 13), whereas most flow occurs in the central and southern parts of the PMOV groundwater basin.

The Sarcobatus Flat segment is constrained from being positioned significantly eastward by water levels, geochemical data, and low-permeability rock. Contrarily, extending the Sarcobatus Flat segment farther westward is unreasonable because it would further worsen the imbalance between recharge (4,400 acre-ft/yr) and discharge (5,600 acre-ft/yr) in the Sarcobatus Flat North groundwater basin (appendix B).

The Cactus Flat segment was drawn at a topographic high between Cactus Flat and Gold Flat where a groundwater divide may form from local recharge. The precise location of the boundary is uncertain, but as discussed in the section, "Alternative Boundary Incorporating Cactus Flat," the boundary does not incorporate Cactus Flat within the PMOV groundwater basin.
The Railroad Valley segment is the most uncertain of the boundary segments for the PMOV groundwater basin. Despite the uncertainty, the Railroad Valley segment is not likely to extend significantly northward into Railroad Valley. This is because groundwater is more likely to flow $20 \mathrm{mi}$ north to a major (80,000 acre-ft/yr; Van Denburgh and Rush, 1974) discharge area in northern Railroad Valley than $50 \mathrm{mi}$ south to a relatively small $(5,900$ acre-ft/yr; Reiner and others, 2002) discharge area in Oasis Valley (pl. 1). The southern path would require flow to occur under little or no hydraulic gradient and through valley fill in Kawich Valley that has a relatively low $\left(1,000 \mathrm{ft}^{2} / \mathrm{d}\right)$ transmissivity.

If the Railroad Valley segment is not a no-flow boundary as conceptualized, and water can flow south across the boundary, a maximum discharge of about 1,000 acre- $\mathrm{ft} / \mathrm{yr}$ is estimated with equation 1 . This estimate of potential interbasin flow assumes a hydraulic gradient of $0.006 \mathrm{ft} / \mathrm{ft}$, a length of $22,000 \mathrm{ft}$, and a transmissivity of $1,000 \mathrm{ft}^{2} / \mathrm{d}$. The gradient from Railroad Valley South into the PMOV groundwater basin is estimated from Willow Witch Well to Lamb Well (fig. 15) and the length is the cross-sectional length of the basin fill along the Railroad Valley segment. The transmissivity is estimated from 18 basin-fill aquifer tests in the Death Valley regional flow system (Belcher and others, 2001) and 3 locally derived specific capacity-tests in basin fill in southern Cactus Flat, northern Gold Flat, and southern Railroad Valley (Cedar Pass WW, TTR Well 53, and Last Stand Well located $12 \mathrm{mi}$ northeast of Willow Witch Well [not shown in figure]; fig. 15). The transmissivities for the 18 aquifer tests have a geometric mean of about $500 \mathrm{ft}^{2} / \mathrm{d}$, whereas the three specific capacity tests have a geometric mean of about $1,300 \mathrm{ft}^{2} / \mathrm{d}$.

The southern and eastern boundaries of the PMOV groundwater basin correspond to topographic (recharge) divides or are parallel to flow directions and were changed little during the analysis. The southern boundary consists of the Bullfrog Hills and Bare Mountain segments, and the eastern boundary consists of the Belted Range and Timber Mountain segments (fig. 15).

The Belted Range segment, extending from Rainier Mesa to the northeastern corner of the PMOV groundwater basin, parallels the spine of the Belted Range. This is a likely hydraulic boundary because the Belted Range receives significant precipitation that is expected to create a groundwater mound beneath the range (pl. 1). Furthermore, a large part of this segment consists of low-permeability siliciclastic rock that impedes flow (fig. 15; Sweetkind and others, 2010; Heilweil and Brooks, 2011). The northern part of this segment has carbonate rock along the boundary, but the carbonate rock is isolated from the regional carbonate aquifer (Belcher and Sweetkind, 2010) and likely does not provide a conduit for flow. Therefore, the location of the Belted Range segment is relatively certain.

The Timber Mountain segment of the PMOV groundwater basin boundary extends from the northeastern end of Bare Mountain to Rainier Mesa (fig. 15). This segment is defined by hydraulic gradients and is drawn parallel to 
groundwater flow. The segment runs through the center of Timber Mountain, which was formed as a resurgent dome of the Ammonia Tanks caldera (Bechtel Nevada, 2002). Timber Mountain may influence groundwater flow, either because of the potential for confining unit rocks in the mountain that restrict flow or because of groundwater mounding on the mountain as a result of local recharge. Water levels in wells that ring the mountain do not provide direct evidence that Timber Mountain has a major influence on flow. High precipitation rates on the mountain (pl. 1) and low groundwater chloride concentrations in wells surrounding the mountain (fig. 9; Rose and others, 2006) indicate that Timber Mountain is a source of recharge. Water levels in this area (Fenelon and others, 2010) were contoured to suggest a divergence of flow away from the mountain and a small influence on heads from local recharge, but no significant mounding was interpreted. The boundary of the Timber Mountain segment is less certain than the Belted Range segment because it is based primarily on water-level data. However, sufficient water-level data are available to constrain the boundary to within several miles of its current position and flow should not cross this boundary regardless of mapped location.

The Bare Mountain segment of the PMOV groundwater basin boundary extends through Bare Mountain (fig. 15). This segment is bounded primarily by Paleozoic and Proterozoic siliciclastic rocks that function as confining units, with some thrusted carbonate rocks that function as isolated carbonate aquifers (Bechtel Nevada, 2002; Fenelon and others, 2010). Additionally, the small amount of local recharge on this mountain has formed a groundwater mound. The low-permeability rocks and mounding restrict flow across this segment.

The Bullfrog Hills segment of the PMOV boundary separates the small amount of locally derived spring flow (100 acre-ft/yr) from the PMOV groundwater basin that discharges to Oasis Valley. Elevated water levels and upland springs support the concept that rocks along this segment are low-permeability and restrict flow from Bullfrog Hills to Oasis Valley.

\section{Conclusions}

The Pahute Mesa-Oasis Valley groundwater basin has been delineated consistently with regional and local constraints. The final Pahute Mesa-Oasis Valley groundwater basin is regionally consistent with adjacent bounding basins, because boundaries are perpendicular to water-level contours and recharge estimates balance measured groundwater discharge in the analyzed basins. Observed conditions in the final delineated Pahute Mesa-Oasis Valley groundwater basin were matched closely with a one-layer, groundwater-flow model to demonstrate local consistency. Simulated water levels, groundwater discharge, and transmissivities matched observed conditions within the measurement errors of each observation type.

Transport of radionuclides from Pahute Mesa can be assessed sufficiently within the final Pahute Mesa-Oasis Valley groundwater basin because water passing through nuclear-test affected areas will discharge to Oasis Valley. The boundary is relatively certain because seven alternative boundaries were considered prior to determining the final Pahute Mesa-Oasis Valley groundwater basin. All 85 nuclear-test locations were well within the 8 boundaries that were investigated.

\section{References Cited}

Allander, K.K., Smith, J.L., and Johnson, M.J., 2009, Evapotranspiration from the lower Walker River Basin, west-central Nevada, water years 2005-07: U.S. Geological Survey Scientific Investigations Report 2009-5079, 62 p.

Avon, Lizanne, and Durbin, T.J., 1994, Evaluation of the Maxey-Eakin method for estimating recharge to groundwater basins in Nevada: American Water Resources Association Water Resources Bulletin, v. 30, no. 1, p. 99-111.

Bechtel Nevada, 2002, A hydrostratigraphic model and alternatives for the groundwater flow and contaminant transport model of Corrective Action Units 101 and 102Central and western Pahute Mesa, Nye County, Nevada: U.S. Department of Energy Report DOE/NV /11718-706, $383 \mathrm{p}$.

Bedinger, M.S., and Harrill, J.R., 2010, Regional potential for interbasin flow of groundwater, in Belcher, W.R., and Sweetkind, D.S., eds., Appendix 1 of Death Valley regional groundwater flow system, Nevada and CaliforniaHydrogeologic framework and transient groundwater flow model: U.S. Geological Survey Professional Paper 1711, p. 345-364.

Belcher, W.R., Elliott, P.E., and Geldon, A.L., 2001, Hydraulic-property estimates for use with a transient ground-water flow model of the Death Valley regional ground-water flow system, Nevada and California: U.S. Geological Survey Water-Resources Investigations Report 01-4210, 29 p., 1 electronic database.

Belcher, W.R., and Sweetkind, D.S., eds., 2010, Death Valley regional ground-water flow system, Nevada and California-Hydrogeologic framework and transient ground-water flow model: U.S. Geological Survey Professional Paper 1711, 398 p. 
Blankennagel, R.K., and Weir, J.E., Jr., 1973, Geohydrology of the eastern part of Pahute Mesa, Nevada Test Site, Nye, County, Nevada: U.S. Geological Survey Professional Paper 712-B, 35 p.

Bredehoeft, J., 2007, It is the discharge: Groundwater, v. 45, no. 5, p. 523-523.

Cardinalli, J.L., Roach, L.M., Rush, F.E., and Vasey, B.J., 1968, State of Nevada hydrographic areas: Nevada Division of Water Resources map, scale 1:500,000.

Cooper, C.A., Hershey, R.L., Healey, J.M., and Lyles, B.F., 2013, Estimation of groundwater recharge at Pahute Mesa using the chloride mass-balance method: Desert Research Institute Publication No. 45251, 99 p.

D’Agnese, F.A., Faunt, C.C., Turner, A.K., and Hill, M.C., 1997, Hydrogeologic evaluation and numerical simulation of the Death Valley regional ground-water flow system, Nevada and California: U.S. Geological Survey WaterResources Investigations Report 96-4300, 124 p.

D’Agnese, F.A., O’Brien, G.M., Faunt, C.C., Belcher, W.R., and San Juan, Carma, 2002, A three-dimensional numerical model of predevelopment conditions in the Death Valley regional ground-water flow system, Nevada and California: U.S. Geological Survey Water-Resources Investigations Report 2002-4102, 114 p.

Daly, C., Halbleib, M., Smith, J.I., Gibson, W.P., Doggett, M.K., Taylor, G.H., Curtis, J., and Pasteris, P.P., 2008, Physiographically sensitive mapping of climatological temperature and precipitation across the conterminous United States: International Journal of Climatology, v. 28, no. 15 , p. 2,031-2,064.

DeMeo, G.A., Laczniak, R.J., Boyd, R.A., Smith, J.L., and Nylund, W.E., 2003, Estimated ground-water discharge by evapotranspiration from Death Valley, California, 1997-2001: U.S. Geological Survey Water-Resources Investigations Report 2003-4254, 27 p.

Dettinger, M.D., 1989, Reconnaissance estimates of natural recharge to desert basins in Nevada, U.S.A., by using chloride-balance calculations: Journal of Hydrology, v. 106, no. 12 , p. 55-78.

Doherty, J., 2010b, Addendum to the PEST manual: Brisbane, Australia, Watermark Numerical Computing.

Doherty, J., 2010a, PEST, Model-independent parameter estimation-User manual (5th ed., with slight additions): Brisbane, Australia, Watermark Numerical Computing.

Doherty, J., and Johnston, J.M., 2003, Methodologies for calibration and predictive analysis of a watershed model: Journal of the American Water Resources Association, v. 39, no. 2, p. 251-265.
Dudley, W.W., Jr., and Larson, J.D., 1976, Effect of irrigation pumping on Desert Pupfish habitats in Ash Meadows, Nye County, Nevada: U.S. Geological Survey Professional Paper 927, 52 p.

Elliott, P.E., and Fenelon, J.M., 2010, Database of groundwater levels and hydrograph descriptions for the Nevada Test Site area, Nye County, Nevada (ver. 4.0, October 2013): U.S. Geological Survey Data Series 533, $16 \mathrm{p}$.

Faunt, C.C., Sweetkind, D.S., and Belcher, W.R., 2010, Three-dimensional hydrogeologic framework model, in Belcher, W.R., and Sweetkind, D.S., eds., chap. E of Death Valley regional ground-water flow system, Nevada and California-Hydrogeologic framework and transient ground-water flow model: U.S. Geological Survey Professional Paper 1711, p. 161-249.

Fenelon, J.M., Sweetkind, D.S., and Laczniak, R.J., 2010, Groundwater flow systems at the Nevada Test Site, Nevada - A synthesis of potentiometric contours, hydrostratigraphy, and geologic structures: U.S. Geological Survey Professional Paper 1771, 54 p., 6 pls.

Fienen, M., Muffels, C., and Hunt, R., 2009, On constraining pilot point calibration with regularization in PEST: Ground Water, v. 47 , no. 6 , p. 835-844.

Flint, A.L., and Flint, L.E., 2007, Application of the basin characterization model to estimate in-place recharge and runoff potential in the Basin and Range carbonate-rock aquifer system, White Pine County, Nevada, and adjacent areas in Nevada and Utah: U.S. Geological Survey Scientific Investigations Report 2007-5099, 20 p.

Flint, A.L., Flint, L.E., Hevesi, J.A., and Blainey, J.M., 2004, Fundamental concepts of recharge in the Desert Southwest - A regional modeling perspective, in Hogan, J.F., Phillips, J.F., Phillips, F.M., and Scanlon, B.R., eds., Groundwater recharge in a desert environment-The southwestern United States: Washington, D.C., American Geophysical Union, Water Science and Applications Series, v. 9, p. 159-184.

Flint, A.L., Flint, L.E., and Masbruch, M.D., 2010, Input, calibration, uncertainty, and limitations of the Basin Characterization Model, in Heilweil, V.M., and Brooks, L.E., eds., Appendix 3 of Conceptual model of the Great Basin carbonate and alluvial aquifer system: U.S. Geological Survey Scientific Investigations Report 20105193, p. 149-163.

Garcia, C.A., Halford, K.J., and Laczniak, R.J., 2010, Interpretation of flow logs from Nevada Test Site boreholes to estimate hydraulic conductivity using numerical simulations constrained by single-well aquifer tests: U.S. Geological Survey Scientific Investigations Report 20105004, 28 p. 
Garcia, C.A., Huntington, J.M., Buto, S.G., Moreo, M.T., Smith, J.L., and Andraski, B.J., 2014, Groundwater discharge by evapotranspiration, Dixie Valley, west-central Nevada, March 2009-September 2011: U.S. Geological Survey Professional Paper 1805, 90 p.

Gesch, D., Evans, G., Mauck, J., Hutchinson, J., Carswell Jr., W.J., 2009, The National Map_Elevation: U.S. Geological Survey Fact Sheet 2009-3053, 4 p.

Grauch, V.J.S., Sawyer, D.A., Fridrich, C.J., and Hudson, M.R., 1999, Geophysical framework of the southwestern Nevada volcanic field and hydrogeologic implications: U.S. Geological Survey Professional Paper 1608, 39 p.

Halford, K.J., 2016, Model archive of Pahute-Mesa Oasis Valley groundwater flow model: U.S. Geological Survey data release, http://dx.doi.org/10.5066/F7N58JFQ.

Harbaugh, A.W., Banta, E.R., Hill, M.C., and McDonald, M.G., 2000, MODFLOW-2000, the U.S. Geological Survey modular ground-water model-User guide to modularization concepts and the ground-water flow process: U.S. Geological Survey Open-File Report 2000-92, 121 p.

Harrill, J.R., 1986, Ground-water storage depletion in Pahrump Valley, Nevada-California, 1962-75: U.S. Geological Survey Water Supply Paper 2279, 53 p.

Harrill, J.R., Gates, J.S., and Thomas, J.M., 1988, Major ground-water flow systems in the Great Basin region of Nevada, Utah, and adjacent states: U.S. Geological Survey Hydrologic Investigations Atlas HA-694-C, 2 sheets.

Heath, R.C., 1983, Basic ground-water hydrology: U.S. Geological Survey Water-Supply Paper 2220, 84 p.

Heilweil, V.M., and Brooks, L.E., eds., 2011, Conceptual model of the Great Basin carbonate and alluvial aquifer system: U.S. Geological Survey Scientific Investigations Report 2010-5193, 191 p.

Hevesi, J.A., 2006, Net infiltration of the Death Valley regional ground-water system, Nevada and California: U.S. Geological geospatial data, accessed September 2013, at http://water.usgs.gov/GIS/metadata/usgswrd/XML/pp1711_ rch_model1.xml.

Hevesi, J.A., Flint, A.L., and Flint, L.E., 2003, Simulation of net infiltration and potential recharge using a distributedparameter watershed model of the Death Valley region, Nevada and California: U.S. Geological Survey Water-Resources Investigations Report 2003-4090, 161 p.

Hunt, C.B., Robinson, T.W., Bowles, W.A., and Washburn, A.L., 1966, Hydrologic basin, Death Valley, California: U.S. Geological Survey Professional Paper 494-B, 138 p.
Jackson, T.R., Halford, K.J., and Garcia, C.A., 2014, Simultaneous numerical analysis of sixteen aquifer tests to estimate hydraulic properties on Pahute Mesa, Nevada National Security Site: U.S. Geological Survey Nevada Water Science Center Aquifer Tests Web page, accessed February 3, 2015, at http://nevada.usgs.gov/water/ AquiferTests/.

Laczniak, R.J., Cole, J.C., Sawyer, D.A., and Trudeau, D.A., 1996, Summary of hydrogeologic controls on groundwater flow at the Nevada Test Site, Nye County, Nevada: U.S. Geological Survey Water-Resources Investigations Report 96-4109, 59 p.

Laczniak, R.J., DeMeo, G.A., Reiner, S.R., Smith, J.L., and Nylund, W.E., 1999, Estimates of ground-water discharge as determined from measurements of evapotranspiration, Ash Meadows Area, Nye County, Nevada: U.S. Geological Survey Water-Resources Investigations Report 99-4079, $70 \mathrm{p}$.

Laczniak, R.J., Flint, A.L., Moreo, M.T., and others, 2008, Ground-water budgets, in Welch, A.H., Bright, D.J., and Knochenmus, L.A., eds., Water resources of the Basin and Range carbonate-rock aquifer system, White Pine County, Nevada, and adjacent areas in Nevada and Utah: U.S. Geological Survey Scientific Investigations Report 2007-5261, 96 p.

Laczniak, R.J., Smith, J.L., and DeMeo, G.A., 2006, Annual ground-water discharge by evapotranspiration from areas of spring-fed riparian vegetation along the eastern margin of Death Valley, 2000-02: U.S. Geological Survey Scientific Investigations Report 2006-5145, 36 p.

Laczniak, R.J., Smith, J.L., Elliot, P.E., DeMeo, G.A., Chatigny, M.A., and Roemer, G.J., 2001, Ground-water discharge determined from estimates of evapotranspiration, Death Valley regional flow system, Nevada and California: U.S. Geological Survey Water-Resources Investigations Report 2001-4195, 51 p.

Malmberg, G.T., 1967, Hydrology of the valley-fill and carbonate-rock reservoirs, Pahrump Valley, NevadaCalifornia: U.S. Geological Survey Water Supply Paper $1832,47 \mathrm{p}$.

Masbruch, M.D., Heilweil, V.M., Buto, S.G., Brooks, L.E., Susong, D.D., Flint, A.L., Flint, L.E., and Gardner, P.M., 2011, Estimated groundwater budgets, in Heilweil, V.M., and Brooks, L.E., eds., chap. D of Conceptual model of the Great Basin carbonate and alluvial aquifer system: U.S. Geological Survey Scientific Investigations Report 2010-5193, p. 73-126. 
Maxey, G.B., and Eakin, T.E., 1951, Ground water in Railroad, Hot Creek, Reveille, Kawich, and Penoyer Valleys, Nye, Lincoln, and White Pine Counties, Nevada, in Eakin, T.E., Maxey, G.B., Robinson, T.W., Fredericks, J.C., and Loeltz, O.J., Contributions to the hydrology of eastern Nevada: Nevada Water Resources Bulletin No. 12, p. $127-171$.

McKee, E.H., Phelps, G.A., and Mankinen, E.A. 2001, The Silent Canyon Caldera-A three-dimensional model as part of a Pahute Mesa-Oasis Valley, Nevada, hydrogeologic model: U.S. Geological Survey Open-File Report 2001-297, $23 \mathrm{p}$.

Moreo, M.T., Laczniak, R.J., and Stannard, D.I., 2007, Evapotranspiration rate estimates of vegetation typical of ground-water discharge areas in the Basin and Range carbonate-rock aquifer system, Nevada and Utah, September 2005-August 2006: U.S. Geological Survey Scientific Investigations Report 2007-5078, 36 p.

National Climatic Data Center, 2013, 1981-2010 normals data access: National Oceanic and Atmospheric Administration National Climatic Data Center Web page, accessed September 2013, at http://www.ncdc.noaa.gov/data-access/ land-based-station-data/land-based-datasets/climatenormals/1981-2010-normals-data.

National Security Technologies, LLC, 2010a, Completion report for well ER-20-7, Corrective Action Units 101 and 102-Central and western Pahute Mesa: U.S. Department of Energy Report DOE/NV 1386, 126 p.

National Security Technologies, LLC, 2010b, Completion report for well ER-EC-11, Corrective Action Units 101 and 102 - Central and western Pahute Mesa: U.S. Department of Energy Report DOE/NV 1435, 146 p.

Navarro-Intera, LLC, 2011, Pahute Mesa well development and testing analyses for wells ER-20-7, ER-20-8 \#2, and ER-EC-11: Navarro-Intera, LLC Report N-I/28091 037, 161 p., accessed September 2015, at http://www.osti.gov/ scitech/biblio/1031914.

Nevada Division of Water Resources, 2015, Well log database query tool: Nevada Division of Water Resources Web page, accessed January 2015, at http://water.nv.gov/.

Pawloski, G.A., Rose, T.P., Meadows, J.W., Deshler, B.J., and Watrus, J., 2002, Categorization of underground nuclear tests on Pahute Mesa, Nevada Test Site, for use in radionuclide transport models: Lawrence Livermore National Laboratory Report UCRL-TR-208347, 235 p.

Pawloski, G.A., Tompson, A.F.B., and Carle, S.F., 2001, Evaluation of the hydrologic source term from the underground nuclear tests on Pahute Mesa at the Nevada Test Site-The CHESHIRE Test: Lawrence Livermore National Laboratory Report UCRL-ID-147023, 507 p.
PRISM Climate Group, 2012, PRISM climate data, 30-year normal, Norm81m data set, created July 2012: Corvallis, Oregon State University PRISM Climate Group Web page, accessed May 2014 at http://prism.oregonstate.edu.

Prothro, L.B., and Drellack, S.L., Jr., 1997, Nature and extent of lava-flow aquifers beneath Pahute Mesa, Nevada Test Site: U.S. Department of Energy Report DOE/NV/11718$156,50 \mathrm{p}$.

RamaRao, B.S., de Marsily, G., and Marietta, M.G., 1995, Pilot point methodology for automated calibration of an ensemble of conditionally simulated transmissivity fields - 1 , Theory and computational experiments: Water Resources Research, v. 31, no. 3, p. 475-493.

Reiner, S.R., Laczniak, R.J., DeMeo, G.A., Smith, J.L., Elliott, P.E., Nylund, W.E., and Fridrich, C.J., 2002, Ground-water discharge determined from measurements of evapotranspiration, other available hydrologic components, and shallow water-level changes, Oasis Valley, Nye County, Nevada: U.S. Geological Survey Water-Resources Investigations Report 2001-4239, 65 p.

Rose, T.P., Benedict, F.C., Thomas, J.M., Sicke, W.S., Hershey, R.L., Paces, J.B., Farnham, I.M., and Peterman, Z.E., 2006, Geochemical data analysis and interpretation of the Pahute Mesa-Oasis Valley groundwater flow system, Nye County, Nevada, August 2002: Lawrence Livermore National Laboratory Report UCRL-TR-224559, 155 p.

Rose, T.P., and Davisson, M.L., 2003, Isotopic and geochemical evidence for Holocene-age groundwater in regional flow systems of south-central Nevada: Geological Society of America Special Paper 368, p. 143-164.

Rush, F.E., 1968, Index of hydrographic areas in Nevada: Nevada Division of Water Resources Information Report 6, $38 \mathrm{p}$.

Rush, F.E., 1970, Regional ground-water systems in the Nevada Test Site area, Nye, Lincoln, and Clark Counties, Nevada: Nevada Department of Conservation and Natural Resources, Water Resources-Reconnaissance Series Report 54, 25 p., accessed September 2015, at http://water.nv.gov/ home/publications/recon/.

Rush, F.E., and Van Denburgh, A.S., 1974, Water-resources appraisal of Railroad and Penoyer Valleys, east-central Nevada: Nevada Department of Conservation and Natural Resources, Water Resources-Reconnaissance Series Report 60, 61 p., accessed September 2015, at http://water.nv.gov/ home/publications/recon/.

San Juan, C.A, Belcher, W.R., Laczniak, R.J., and Putnam, H.M., 2010, Hydrologic components for model development, in Belcher, W.R., and Sweetkind, D.S., eds., chap. C of Death Valley regional ground-water flow system, Nevada and California-Hydrogeologic framework and transient ground-water flow model: U.S. Geological Survey Professional Paper 1711, p. 95-132. 
Sawyer, D.A., Fleck, R.J., Lanphere, M.A., Warren, R.G., Broxton, D.E., and Hudson, M.R., 1994, Episodic caldera volcanism in the Miocene southwestern Nevada volcanic field-Revised stratigraphic framework, $40 \mathrm{Ar} / 39 \mathrm{Ar}$ geochronology, and implications for magmatism and extension: Geological Society of America Bulletin, v. 106, p. 1,304-1,318.

Smith, J.L., Laczniak, R.J., Moreo, M.T., and Welborn, T.L., 2007, Mapping evapotranspiration units in the Basin and Range carbonate-rock aquifer system, White Pine County, Nevada, and adjacent parts of Nevada and Utah: U.S. Geological Survey Scientific Investigations Report 2007-5087, $20 \mathrm{p}$.

Soulé, D.A., 2006, Climatology of the Nevada Test Site: National Oceanic and Atmospheric Administration, Air Resources Laboratory, Special Operations and Research Division Technical Memorandum SORD 2006-3, 165 p.

Stoller-Navarro Joint Venture, 2009, Phase I transport model of Corrective Action Unit 101 and 102 - Central and western Pahute Mesa, Nevada Test Site, Nye County, Nevada: Stoller-Navarro Joint Venture Report S-N/99205 111, Revision No. 1, 696 p.

Stonestrom, D.A., Prudic, D.E., Walvoord, M.A., Abraham, J.D., Stewart-Deaker, A.E., Glancy, P.A., Constantz, Jim, Laczniak, R.J., and Andraski., B.J., 2007, Focused ground-water recharge in the Amargosa Desert basin, in Stonestrom, D.A., Constantz, Jim, Ferre, T.P.A., and Leake, S.A., eds., chap. E of Ground-water recharge in the arid and semiarid southwestern United States: U.S. Geological Survey Professional Paper 1703E, 136 p.

Sweetkind, D.S., Belcher, W.R., Faunt, C.C., and Potter, C.J., 2010, Geology and hydrogeology, in Belcher, W.R., and Sweetkind, D.S., eds., chap. B of Death Valley regional ground-water flow system, Nevada and CaliforniaHydrogeologic framework and transient ground-water flow model: U.S. Geological Survey Professional Paper 1711, p. 19-94.

U.S. Department of Energy, 1997a, Regional groundwater flow and tritium transport modeling and risk assessment of the Underground Test Area, Nevada Test Site, Nevada: U.S. Department of Energy Report DOE/NV 477, 396 p.

U.S. Department of Energy, 1997b, Completion report for well cluster ER-20-5: U.S. Department of Energy Report DOE/ NV 466, 158 p., accessed September 2015, at http://www. osti.gov/scitech/biblio/631143-completion-report-wellcluster-er.

U.S. Department of Energy, 1999, Corrective action investigation plan for Corrective Action Units 101 and 102 - Central and western Pahute Mesa, Nevada Test Site, Nevada: U.S. Department of Energy Report DOE/NV 516, $350 \mathrm{p}$.
U.S. Department of Energy, 2009, Phase II corrective action investigation plan for Corrective Action Units 101 and 102 - Central and western Pahute Mesa, Nevada Test Site, Nye County, Nevada: U.S. Department of Energy Report DOE/NV 1312, Rev. 2, 255 p.

U.S. Department of Energy, 2010, Environmental restoration: U.S. Department of Energy Fact Sheet DOE/NV 537, Rev. 4, 2 p., accessed September 2013, at http://www. nv.energy.gov/library/factsheets/DOENV_537.pdf.

U.S. Geological Survey, 2008, Documentation of computer program INFIL3.0-A distributed-parameter watershed model to estimate net infiltration below the root zone: U.S. Geological Survey Scientific Investigations Report 2008-5006, 98 p.

U.S. Geological Survey, 2015a, National Water Information System-USGS 10251217 AMARGOSA RV AT BEATTY, NV: U.S. Geological Survey database, accessed January 2015, at http://waterdata.usgs.gov/nv/nwis/ inventory/?site_no=10251217\&agency_cd=USGS\&amp.

U.S. Geological Survey, 2015b, National Water Information System-USGS water data for Nevada: U.S. Geological Survey database, accessed January 2015, at http://waterdata. usgs.gov/nv/nwis/.

Van Denburgh, A.S., and Rush, F.E., 1974, Water-resources appraisal of Railroad and Penoyer Valleys, east-central Nevada: Nevada Department of Conservation and Natural Resources, Water Resources-Reconnaissance Series Report 60, $61 \mathrm{p}$.

Waddell, R.K., 1982, Two-dimensional, steady-state model of ground-water flow, Nevada Test Site and vicinity, NevadaCalifornia: U.S. Geological Survey Water-Resources Investigations Report 82-4085, 72 p., 1 pl.

White, A.F., 1979, Geochemistry of ground water associated with tuffaceous rocks, Oasis Valley, Nevada: U.S. Geological Survey Professional Paper 712-E, 25 p.

Wolfsberg, Andrew, Glascoe, Lee, Lu, Guoping, Olson, Alyssa, Lichtner, Peter, McGraw, Maureen, Cherry, Terry, and Roemer, Guy, 2002, TYBO/BENHAM-Model analysis of groundwater flow and radionuclide migration from underground nuclear tests in southwestern Pahute Mesa, Nevada: Los Alamos National Laboratory Report LA-13977, $490 \mathrm{p}$.

Wood, D.B., 2007, Digitally available interval-specific rocksample data compiled from historical records, Nevada National Security Site and vicinity, Nye County, Nevada (ver. 2.1, August 2015): U.S. Geological Survey Data Series 297, 20 p., accessed September 2015, at http://dx.doi. org/10.3133/ds297. 
This page intentionally left blank. 


\section{Appendix A. Revised Groundwater Discharge Estimates for Death Valley and Sarcobatus Flat, Nevada and California}

\section{Death Valley}

Mean annual groundwater discharge of 30,000 acre-ft/yr from Death Valley was estimated for this study by compiling and evaluating estimates from previous studies (table A1). Hunt and others (1966) described the general geology, hydrology, and geochemistry of Death Valley in a comprehensive investigation; however, techniques for measuring evaporation and transpiration during this early study period were rudimentary. DeMeo and others (2003) used micrometeorological measurements to estimate groundwater discharge from the playa and phreatophytic vegetation. Laczniak and others (2006) also used micrometeorological measurements to estimate discharge from springs on the eastern margin of Death Valley. Spring flows measured for numerous previous studies were compiled by San Juan and others (2010).

The playa groundwater discharge rates estimated by DeMeo and others (2003) using the Bowen ratio energy budget (BREB) method are considered unreliable and were not used for this study. The BREB method is not able to accurately measure the extremely low rates of evaporation that occur on the playa (Tyler and others, 1997); therefore, groundwater discharge from the playa was re-estimated for this study.

DeMeo and others (2003) divided the playa into two ET units based on surficial characteristics. One unit is dominated by bare soil (bare-soil playa [BSP]; 76,000 acres) and the other by salt crusts (salt-encrusted playa [SEP];
21,000 acres). Measurements were made at two sites, one in each ET unit, for varying time intervals between August 1997 and July 2001. Reported mean daily evaporation rates based on these measurements were $0.007 \mathrm{in} / \mathrm{d}$ at the BSP site and $0.006 \mathrm{in} / \mathrm{d}$ at the SEP site. After subtracting local precipitation, the estimated mean daily groundwater discharge rates at these sites $(0.005 \mathrm{in} / \mathrm{d}$ at the BSP site and $0.004 \mathrm{in} / \mathrm{d}$ at the SEP site) were assumed by DeMeo and others (2003) to be representative of each ET unit.

The BREB method relies on an energy balance approach to estimate evaporation. Solar irradiation at the land surface is the primary source of available energy driving evaporation processes. This available energy is partitioned into either latent- or sensible-heat energy. Sensible heat is the movement of heat energy that results from a temperature difference between the surface and the atmosphere. Latent heat is the energy consumed converting water from the liquid to vapor phase. The Bowen ratio is computed by dividing sensible-heat flux by latent-heat flux. The proportion of sensible- to latentheat flux is based on differential measurements of temperature and vapor pressure at two heights above the surface of interest. Greater water availability means that a greater proportion of available energy is partitioned into latent-heat flux, which results in a lower Bowen ratio. As water becomes less readily available, a greater proportion of available energy is partitioned into sensible-heat flux, which results in a higher Bowen ratio.

Table A1. Estimated annual groundwater discharge and uncertainty in discharge estimates, Death Valley, California.

[Total rounded to nearest thousand acre feet]

\begin{tabular}{lccl}
\hline Groundwater discharge component & $\begin{array}{c}\text { Mean annual } \\
\text { groundwater } \\
\text { discharge } \\
\text { (acre-feet) }\end{array}$ & $\begin{array}{c}\text { Estimated } \\
\text { percent } \\
\text { accuracy } \\
\text { (plus or } \\
\text { minus) }\end{array}$ & \multicolumn{1}{c}{ Reference } \\
\hline High-density vegetation & 4,500 & 20 & DeMeo and others (2003) \\
Moderate-density vegetation & 10,000 & 20 & DeMeo and others (2003) \\
Low-density vegetation & 6,600 & 20 & DeMeo and others (2003) \\
Staininger Spring & 306 & 15 & San Juan and others (2010) \\
Grapevine Springs area & 790 & 15 & Laczniak and others (2006) \\
Texas Spring & 361 & 15 & San Juan and others (2010) \\
Travertine Springs & 1,370 & 10 & San Juan and others (2010) \\
Nevares Spring & 558 & 15 & San Juan and others (2010) \\
Saltpan run-on & 1,370 & 50 & Hunt and others (1966) \\
Bare-soil playa & 3,800 & 100 & Garcia and others (2014); this report \\
Salt-encrusted playa & 500 & 100 & Garcia and others (2014); this report \\
\cline { 2 - 3 } Total & 30,000 & 15 & \\
\hline
\end{tabular}


As the vapor-pressure difference decreases and the Bowen ratio increases (in drier environments), the relative error in the computed latent-heat flux (evaporation) increases because the absolute error that results from computing the Bowen ratio increases. The BREB method generally is considered to give acceptable results in moist environments where the vapor-pressure difference between measuring sensors is large. In dry environments, however, the vaporpressure difference between measuring sensors can be very small; therefore, the error in determining the Bowen ratio can lead to unacceptably large errors in the latent-heat flux (Angus and Watts, 1984).

The playa of Death Valley is one of the hottest and most arid places in the Western Hemisphere, with mean annual rainfall of $2.26 \mathrm{in}$. and summer temperatures commonly exceeding $120^{\circ} \mathrm{F}$ (DeMeo and others, 2003). As a result, the exceptionally small vapor pressure differential can constrain BREB evaporation only to within $0.01 \mathrm{in} / \mathrm{d}$ (Angus and Watts, 1984), indicating that the evaporation measurements of DeMeo and others (2003) (0.007 in/d for BSP and 0.006 in/d for SEP) may underestimate evaporation by about 45 and 80 percent respectively, or overestimate evaporation by several orders of magnitude. Seventy-one and 87 percent of measured daily evaporation rates were less than $0.01 \mathrm{in} / \mathrm{d}$ for the BSP and SEP sites, respectively; therefore, the work of DeMeo and others (2003) indicates that the typical evaporation rate is less than $0.01 \mathrm{in} / \mathrm{d}$, but no absolute magnitude may be reliably inferred.

Evaporation measurements made by DeMeo and others (2003) and computed regional groundwater discharge also were compromised by surface-water inundation caused by a series of flood events during 1998 (Tanko and Glancy, 2001) and 2001. The volume of surface water inundating the measurement source areas, and the proportion that was stored temporarily in the shallow playa deposits could not be determined precisely at the time of the DeMeo and others (2003) study; therefore, the contribution of this surface-water source to evaporation measurements and regional groundwater discharge calculations is not known. An attempt was made to eliminate flooded periods from the measurement record; however, there was no attempt to account for the storage of flood waters either in the saturated or unsaturated zone. An unmeasured and unaccounted surface-water source would cause regional groundwater discharge estimates to be biased high. Accordingly, the annual rates reported by DeMeo and others (2003) of $0.005 \mathrm{in} / \mathrm{d}(0.15 \mathrm{ft} / \mathrm{yr})$ for BSP and $0.004 \mathrm{in} / \mathrm{d}$ $(0.13 \mathrm{ft} / \mathrm{yr})$ for SEP represent both surface-water inputs and regional groundwater discharge.

Groundwater discharge from any playa is particularly difficult to estimate accurately because rates are low and spatially variable. Generally, rates of groundwater discharge from playas are low because:

1. Saturated hydraulic conductivities for the fine-grained playa sediments are extremely low;
2. Small hydraulic-head differences in these topographically flat areas result in low hydraulic gradients;

3. High salt concentrations reduce saturation vapor pressures and vapor-pressure differences between the surface and atmosphere, resulting in reduced evaporation (relative to non-saline environments); and

4. A concentration gradient between fresh regional groundwater moving toward the playa and saline groundwater in the playa limits exchange between the two.

Studies completed after DeMeo and others (2003) provide improved measurement methods and an improved understanding of the physical processes that control the rate of groundwater evaporation from desert playas (Kampf and others, 2005; Garcia and others, 2014).

Groundwater discharge estimates for the Death Valley playa were re-estimated (table A1) by applying rates from Dixie Valley, Nevada (Garcia and others, 2014). Dixie Valley is about 250 mi north of Death Valley. Evaporation was measured at two playa sites in Dixie Valley for 2 years using the eddy-covariance method. The estimated uncertainty for these eddy-covariance evaporation measurements was $0.002 \mathrm{in} / \mathrm{d}$, a fivefold improvement over the BREB method. This uncertainty threshold was exceeded at playa measurement sites by more than 90 percent of measured daily evaporation rates. Computed mean annual groundwater discharge rates were $0.07 \mathrm{ft}$ at a site $1.2 \mathrm{mi}$ from the playa edge and $0.04 \mathrm{ft}$ at a site $1.6 \mathrm{mi}$ from the playa edge. The mean combined annual groundwater discharge rate for both sites of $0.05 \mathrm{ft}$ was used instead of the $0.15 \mathrm{ft}$ estimated for BSP by DeMeo and others (2003). This resulted in a mean annual groundwater discharge from the BSP of 3,800 acre-ft/yr $(0.05 \mathrm{ft} / \mathrm{yr} \times 76,000 \mathrm{acres})$. Annual groundwater discharge was re-estimated for SEP by applying one-half $(0.025 \mathrm{ft})$ of the re-estimated BSP rate, because regional groundwater discharging from the salt encrusted part of the playa is greatly restricted by the presence of perennial salt crusts. Salt crusts at the surface can limit capillary rise or form impermeable barriers to liquid water. Additionally, less energy is available to drive evaporation processes because a greater amount of incoming solar radiation is reflected away by the light-colored surface (Kampf and others, 2005). Mean annual groundwater discharge from the SEP is estimated at about 500 acre-ft/yr $(0.025 \mathrm{ft} / \mathrm{yr} \times 21,000$ acres) (table A1).

The degree to which regional groundwater discharge measurements from the playa in Dixie Valley are applicable to Death Valley is not known. Increased uncertainty and the potential for systematic bias occur when groundwater discharge rates are applied outside their basin of origin. However, discharging playas have many common variables that control the rate of groundwater discharge. Fine-textured sediments, high salinity, and great hydraulic resistance to groundwater movement all result in low evaporation rates. 
Kampf and others (2005) noted that soil texture controlled evaporation rates rather than evaporative demand by the atmosphere, so the warmer climate in Death Valley may not be a large factor.

It is clear, however, from the comprehensive evaluation by Hunt and others (1966) that the extensive playa surface in Death Valley is extremely complex. The rate of groundwater discharge is likely to vary spatially. Salt depositional processes result in surface textures that cover a full spectrum from smooth to extremely rough, and salt deposits that range from a few inches to a few feet thick. Some areas of the playa are subject to surface-water flooding. There is evidence of preferential flow through tubular orifices discharging groundwater to the surface. Furthermore, groundwater discharging from the playa likely is greater near relatively large inflow points. The occurrence of shallow groundwater in Death Valley is indicated by springs and phreatophytes where groundwater is forced near the surface by faults, impervious structural barriers, and where coarse gravel and sand grades laterally to silt and clay within the playa. Groundwater discharging to the playa likely is greatest in areas adjacent to springs and phreatophytes, such as (1) in the northernmost part (Cotton Ball Basin) downgradient of Mesquite Flat, which is drained by Salt Creek; (2) in the northeastern part downgradient of the Furnace Creek Wash; and (3) in the southwestern part downgradient of the Panamint Range. Contrarily, groundwater discharge to the playa likely is negligible away from active discharge areas. This potential spatial variability in evaporation rates has not been measured by any previous studies, nor is it captured by the estimates presented in the current study. Consequently, the estimated accuracy of playa evaporation estimates for the current study is assumed to be 100 percent (table A1).

\section{Sarcobatus Flat}

The annual groundwater discharge estimate for Sarcobatus Flat of 13,000 acre-ft from Laczniak and others (2001) (table A2) was reevaluated for this study because modeling efforts were unable to support this volume of groundwater flow using reasonable assumptions. Furthermore, recent studies indicate that groundwater discharge rates for the shrubland ET unit are substantially less than estimated by Laczniak and others (2001) for Sarcobatus Flat. About 75 percent of the estimated groundwater discharge in Sarcobatus Flat was attributed to the sparse to moderately dense shrubland ET unit (table A2). This discharge was based on an estimated shrubland rate of $0.50 \mathrm{ft} / \mathrm{yr}$, which was downscaled from a measured rate of $0.70 \mathrm{ft} / \mathrm{yr}$ in Oasis Valley using the BREB method (Laczniak and others 2001). More recent studies in central Nevada have used updated and more accurate measurement methods to estimate annual groundwater discharge rates of $0.29 \mathrm{ft}$ for the sparse shrubland ET unit in Snake Valley (Moreo and others, 2007; Laczniak and others, 2008); $0.30 \mathrm{ft}$ for the combined sparse, moderately dense, and dense shrubland ET units in Spring Valley (Moreo and others, 2007; Laczniak and others, 2008); $0.33 \mathrm{ft}$ for the moderate-to-dense shrubland ET unit in Dixie Valley (Garcia and others, 2014); and $0.30 \mathrm{ft}$ for the shrubland ET unit in Kobeh Valley (D.L. Berger, U.S. Geological Survey, written commun., 2015). The downscaling of the shrubland discharge rate from Oasis Valley to Sarcobatus Flat by Laczniak and others (2001) was based on differences in shrubland density. The difference in shrubland density between the two valleys was determined by a remote-sensing derived vegetation index (modified soil adjusted vegetation index [MSAVI]; Qi and others, 1994). Laczniak and others (2001) noted that one of the factors potentially affecting the accuracy of the groundwater discharge estimate in Sarcobatus Flat was "uncertainty in estimates of ET rates based on computed relative density differences." Furthermore, Laczniak and others (2001) noted that no ET measurement sites were instrumented in the discharge area of Sarcobatus Flat, and that in-situ ET measurements "would help refine, improve, and provide more confidence in estimates of mean annual ground-water discharge."

Although direct measurements of ET using the eddy-covariance method would be the most accurate method of estimating groundwater discharge from the shrubland ET unit in Sarcobatus Flat, an effort of this magnitude was outside the scope of this study. Instead, a vegetation-index analysis was done that included the shrubland areas of Sarcobatus Flat, Oasis Valley, and the sparse shrubland ET unit in Snake Valley. The intent of the vegetation-index analysis was (1) to evaluate the distribution of shrubland density for similarities or differences among these valleys, where the mean annual precipitation rate is similar (about $0.5 \mathrm{ft}$ ); and (2) to determine whether a new estimate was warranted based on recent insights into shrubland discharge processes and more accurate measurements. Moreo and others (2007) 
reported that precipitation was a primary factor affecting annual groundwater usage by shrubland at three measurement sites with similar shrub density in three valleys in east-central Nevada. Snake Valley was included in the analysis because the groundwater discharge area is characterized by a widespread shrubland distribution supported by diffuse groundwater flow either from underlying regional aquifers or from deeper alluvial systems. These discharge area characteristics are similar to those in Sarcobatus Flat but distinctly different from characteristics in Oasis Valley. The groundwater discharge area in Oasis Valley is characterized by a large concentration of fault-controlled springs, with high-density populations of phreatophytes distributed along the spring pools and drainages (Reiner and others, 2002). Spring flow is concentrated primarily in the Amargosa River channel, which flows perennially for short reaches just downgradient of the major springs.

A histogram was constructed for the shrubland ET unit in each valley from mean MSAVI values representing nearpeak vegetation densities from 2005 through 2008 (fig. A1). MSAVI values were extracted from Landsat 5 Spectral Index data (Masek and others, 2006). Shrubland ET units delineated for previous studies were used to define the shrubland areasunit 8 from Laczniak and others (2001) was used for Oasis Valley and Sarcobatus Flat, and unit 6 from Smith and others (2007) was used for Snake Valley. A summer date for each year was selected for each valley with a target date of midJuly to minimize the effect of annual vegetation. If imagery was not available in that time frame or unsuitable because of cloud cover, dates were allowed to range from late June to late August. The MSAVI is an index that attempts to remove soil influences where vegetation densities are sparse. Because sparsely vegetated conditions are present in these valleys, the MSAVI is considered an appropriate index from which to map differences in vegetation density. Higher MSAVI values were assumed to equate to greater shrub density. The histogram indicates that the shrub density in Snake Valley and Oasis Valley are about 33 and 50 percent more dense, respectively, than in Sarcobatus Flat.

Based on the difference in shrubland density, the similarity in precipitation rates, and the similarity in groundwater discharge area characteristics, the shrubland groundwater discharge rate in Sarcobatus Flat is likely to be substantially less than in Snake Valley. The annual groundwater discharge rate estimated for the sparse shrubland ET unit in Snake Valley is $0.29 \mathrm{ft}$. Assuming a reduction of groundwater discharge by about one-third, which is equivalent to the difference in shrubland density, the annual groundwater discharge rate for the shrubland ET unit in Sarcobatus Flat is $0.20 \mathrm{ft}$; therefore, annual groundwater discharge in Sarcobatus Flat is estimated at 7,500 acre-ft (table A2). The re-estimated groundwater discharge rate of $0.20 \mathrm{ft} / \mathrm{yr}$ compares well to $0.17 \mathrm{ft} / \mathrm{yr}$ measured at an eddy-covariance station at a low-density shrubland site (LDV) in Dixie Valley (Garcia and others, 2014). The mean MSAVI value for Dixie Valley computed within the source area of the eddycovariance station was 0.058 for summer scenes from 2008 to 2011, which is almost identical to 0.057 mean MSAVI value computed for the shrubland ET unit in Sarcobatus Flat. Precipitation in Dixie Valley was $0.53 \mathrm{ft} / \mathrm{yr}$, which also is

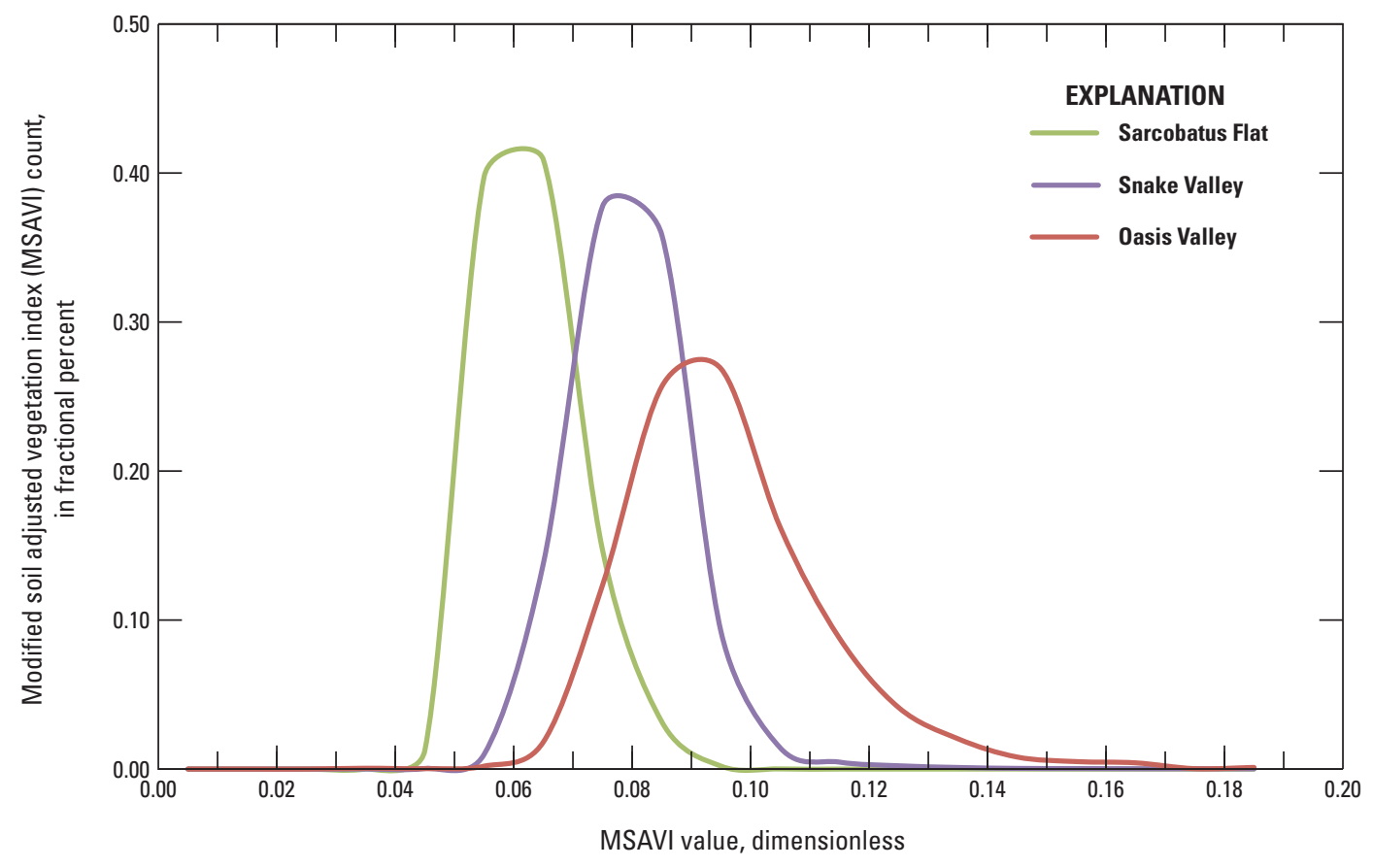

Figure A1. Histogram showing shrubland density distribution in Sarcobatus Flat, Snake Valley, and Oasis Valley, Nevada. 
similar to the values for Snake Valley and Sarcobatus Flat. This simple analysis does not attempt to account for other factors that could affect groundwater usage by phreatophytic shrubland in arid and semi-arid environments such as soil physical and hydraulic properties, nor does it include any in-situ measurements; therefore, a relatively wide uncertainty range of $\pm 0.10 \mathrm{ft}$ is assumed. Accordingly, groundwater discharge in Sarcobatus Flat is estimated to range from 5,500 to 9,500 acre-ft/yr.

\section{References Cited}

Angus, D.E., and Watts, P.J., 1984, EvapotranspirationHow good is the Bowen ratio method?: Agricultural Water Management, v. 8, p. 133-150.

DeMeo, G.A., Laczniak, R.J., Boyd, R.A., Smith, J.L., and Nylund, W.E., 2003, Estimated ground-water discharge by evapotranspiration from Death Valley, California, 1997-2001: U.S. Geological Survey Water-Resources Investigations Report 2003-4254, 27 p., http://pubs.er.usgs. gov/publication/wri034254.

Garcia, C.A., Huntington, J.M., Buto, S.G., Moreo, M.T., Smith, J.L., and Andraski, B.J., 2014, Groundwater discharge by evapotranspiration, Dixie Valley, west-central Nevada, March 2009-September 2011: U.S. Geological Survey Professional Paper 1805, 90 p., http://pubs.er.usgs. gov/publication/pp1805.

Hunt, C.B., Robinson, T.W., Bowles, W.A., and Washburn, A.L., 1966, Hydrologic basin, Death Valley, California: U.S. Geological Survey Professional Paper 494-B, 138 p., http:// pubs.er.usgs.gov/publication/pp494B.

Kampf, S.K., Tyler, S.W., Ortiz, C.A., Muñoz, J.F., and Adkins, P.L., 2005, Evaporation and land surface energy budget at the Salar de Atacama, northern Chile: Journal of Hydrology, v. 310, p. 236-252.

Laczniak, R.J., Flint, A.L., Moreo, M.T., and others, Ground-water budgets, in Welch, A.H., Bright, D.J., and Knochenmus, L.A., eds., 2008, Water resources of the Basin and Range carbonate-rock aquifer system, White Pine County, Nevada, and adjacent areas in Nevada and Utah: U.S. Geological Survey Scientific Investigations Report 2007-5261, 96 p., http://pubs.er.usgs.gov/publication/ sir20075261.

Laczniak, R.J., Smith, J.L., and DeMeo, G.A., 2006, Annual ground-water discharge by evapotranspiration from areas of spring-fed riparian vegetation along the eastern margin of Death Valley, 2000-02: U.S. Geological Survey Scientific Investigations Report 2006-5145, 36 p., http://pubs.er.usgs. gov/publication/sir20065145.
Laczniak, R.J., Smith, J.L., Elliot, P.E., DeMeo, G.A., Chatigny, M.A., and Roemer, G.J., 2001, Ground-water discharge determined from estimates of evapotranspiration, Death Valley regional flow system, Nevada and California: U.S. Geological Survey Water-Resources Investigations Report 2001-4195, 51 p., http://pubs.er.usgs.gov/ publication/wri014195.

Masek, J.G., Vermote, E.F., Saleous, N., Wolfe, R., Hall, F.G., Huemmrich, F., Gao, F., Kutler, J., and Lim, T.K., 2006, A Landsat surface reflectance data set for North America, 1990-2000: IEEE Geoscience and Remote Sensing Letters, v. 3 , p. $68-72$.

Moreo, M.T., Laczniak, R.J., and Stannard, D.I., 2007, Evapotranspiration rate estimates of vegetation typical of ground-water discharge areas in the Basin and Range carbonate-rock aquifer system, Nevada and Utah, September 2005-August 2006: U.S. Geological Survey Scientific Investigations Report 2007-5078, 36 p., http:// pubs.er.usgs.gov/publication/sir20075078.

Qi, J., Chehbouni, A., Huete, A.R., Kerr, Y.H., and Sorooshian, S., 1994, A modified soil adjusted vegetation index: Remote Sensing of Environment, v. 48, p. 119-126.

Reiner, S.R., Laczniak, R.J., DeMeo, G.A., Smith, J.L., Elliott, P.E., Nylund, W.E., and Fridrich, C.J., 2002, Ground-water discharge determined from measurements of evapotranspiration, other available hydrologic components, and shallow water-level changes, Oasis Valley, Nye County, Nevada: U.S. Geological Survey Water-Resources Investigations Report 2001-4239, 65 p., http://pubs.er.usgs. gov/publication/wri014239.

San Juan, C.A, Belcher, W.R., Laczniak, R.J., and Putnam, H.M., 2010, Hydrologic components for model development, in Belcher, W.R., and Sweetkind, D.S., eds., chap. C of Death Valley regional ground-water flow system, Nevada and California-Hydrogeologic framework and transient ground-water flow model: U.S. Geological Survey Professional Paper 1711, p. 95-132.

Smith, J.L., Laczniak, R.J., Moreo, M.T., and Welborn, T.L., 2007, Mapping evapotranspiration units in the Basin and Range carbonate-rock aquifer system, White Pine County, Nevada, and adjacent parts of Nevada and Utah: U.S. Geological Survey Scientific Investigations Report 2007-5087, 20 p., http://pubs.er.usgs.gov/publication/ $\operatorname{sir} 20075087$.

Tanko, D.J., and Glancy, P.A., 2001, Flooding in the Amargosa River Drainage Basin, February 23-24, 1998, southern Nevada and eastern California, including the Nevada Test Site: U.S. Geological Survey Fact Sheet 036-01, 4 p.

Tyler, S.W., Kranz, S., Parlange, M.B., Albertson, J., Katul, G.G., Cochran, G.F., Lyles, B.A., and Holder, G., 1997, Estimation of groundwater evaporation and salt flux from Owens Lake, California, USA: Journal of Hydrology, v. 200, nos. 1-4, p. 110-135. 


\section{Appendix B. Regional Analysis to Balance Recharge and Discharge in Pahute Mesa-Oasis Valley and Surrounding Groundwater Basins, Nevada and California}

A macro-driven Microsoft Excel ${ }^{\circledR}$ workbook was developed to simultaneously balance recharge and discharge in Pahute Mesa-Oasis Valley and all surrounding groundwater basins. The workbook allows for as many as four precipitation ranges to be manually specified for the modified Maxey-Eakin approach. Precipitation for the area within each range is summed by groundwater basin and multiplied by a fitted coefficient to estimate precipitation-derived recharge. For the water balance method using INFILv3, the workbook allows for the scaling of the INFILv3 recharge data set, which is then summed by groundwater basin. The workbook also allows for interbasin flow to be specified as part of the recharge or discharge total. A best fit is obtained by manually changing the precipitation ranges or INFILv3 scaling factor, balancing recharge and discharge, and comparing RMS errors between models with different ranges or scaling factors until the error can no longer be reduced.
Analyses are available for download at http://dx.doi. org/10.3133/sir20155175 in the zip file AppendixB BasinBALANCE.zip, which contains two Microsoft Excel ${ }^{\circledR}$ workbooks:

1. BasinBALANCE_PRISM.T8_v2.xlsm-Workbook that simultaneously balances PRISM precipitation estimates with groundwater discharge estimates in multiple basins using a modified Maxey-Eakin approach. Results are on the worksheet "BAL." See "readme" worksheet for explanation of worksheets.

2. BasinBALANCE_INFIL.v8_v2.xlsm-Workbook that simultaneously balances INFILv3 recharge estimates with groundwater discharge estimates in multiple basins. Results are on the worksheet "BAL". See "readme" worksheet for explanation of worksheets.

Both workbooks contain macros, which need to be enabled to activate the spreadsheets. 
Publishing support provided by the U.S. Geological Survey

Publishing Network, Tacoma Publishing Service Center

For more information concerning the research in this report, contact the Director, Nevada Water Science Center

U.S. Geological Survey

2730 N. Deer Run Rd.

Carson City, NV 89701

http://nevada.usgs.gov/water/ 
产

営 